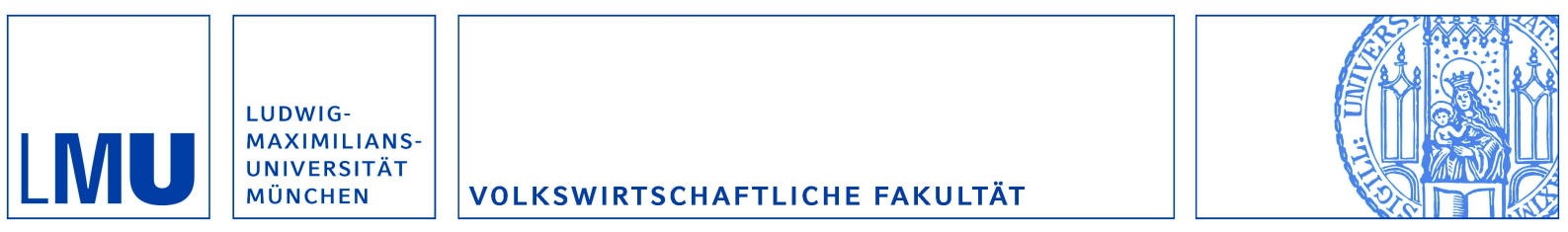

Ebner, André:

A micro view on home equity withdrawal and its determinants. Evidence from Dutch households

Munich Discussion Paper No. 2010-2

Department of Economics

University of Munich

Volkswirtschaftliche Fakultät

Ludwig-Maximilians-Universität München

Online at https://doi.org/10.5282/ubm/epub. 11309 


\title{
A micro view on home equity withdrawal and its determinants Evidence from Dutch households
}

\author{
André Ebner*
}

Abstract: Home equity is the most important part of a household portfolio, but only recently has it become more accessible through innovations in the mortgage market and financial deregulation. This study looks at the factors driving home equity withdrawal on a household level using Dutch survey data and assesses to which degree different theoretical predictions can be empirically supported. There is little evidence that equity withdrawal is used as a buffer against adverse income shocks, with financial motives and life-cycle effects likely to dominate a household's decision. Finally, the study provides first evidence of the impact of changing supply side conditions on home equity withdrawal.

Keywords: home equity withdrawal, Dutch housing market, consumption models

JEL Classification: D1, D9, E2, E4, G2

\footnotetext{
- Acknowledgments: This paper makes use of data of the DNB Household Survey. I am very grateful to Linda Rousovà, Rien Wagenvoort, Joachim Winter, Amelie Wuppermann, and participants at the $1^{\text {st }}$ ReCapNet conference at the ZEW Mannheim for useful comments on earlier versions of this paper.

${ }^{*}$ Munich Graduate School of Economics, LMU Munich, Kaulbachstr. 45, D-80539 Munich, Germany, Tel.: 0049 (0)89 21803113, e-mail: andre.ebner@1rz.uni-muenchen.de.
} 


\section{Introduction}

In the Netherlands as well as in other countries like the UK and the USA, housing represents the largest share of assets and liabilities of a household's balance sheet. In the last two decades it has become easier and less costly to access home equity due to new mortgage products, financial deregulation, and increased competition in the provision of financial services (see Scanlon et al. 2008), making it a potentially important source of finance. Homeowners can either take out a mortgage or remortgage with a higher principal, or they can move to cheaper or rental accommodation to use the equity retained in their houses. ${ }^{1}$ Due to the shortage of informative micro datasets, only few and very recent studies analyse empirically for the UK, Australia, and the USA (see e.g. Banks 2009; Schwartz et al. 2008; Hurst and Stafford 2004), when households withdraw home equity. This study adds evidence on continental Europe and tests the implications from theoretical models incorporating home equity withdrawal, using information from the Dutch National Bank Household Survey (DHS) for the period 2004 to 2007. In the European context the Dutch housing market has been one of the most dynamic since the early 1990s, characterised by an innovative and varied mortgage market and a very generous system of tax deductibility for mortgage interest rates, making it a particularly interesting case to study HEW.

The concentration of wealth in housing is likely to have major implications for households and on an aggregate level for the economy. From a macro perspective it is therefore important to understand how fluctuations in home equity feed into the economy, with potential channels reaching from direct wealth effects to collateral effects (see Buiter 2008; Iacoviello 2005; Aoki et al. 2004). There have also been studies assessing the impact of housing wealth and HEW on growth, business cycle fluctuations, and consumption (e.g. Campbell and Cocco 2007; Case et al. 2005; Dvornak and Kohler 2003; Boone et al. 2001; Muellbauer and Murphy 1997, 1990; Attanasio and Weber 1995). ${ }^{2}$ With respect to the latter, aggregated data have shown a positive correlation between home equity withdrawal (HEW) and consumption, but there is no consensus whether there is a causal relationship. ${ }^{3}$ Recently, mortgage borrowing in general and HEW in particular are attracting attention due to their role in the subprime crisis in the USA, which led to the global economic downturn (for recent studies see e.g. Khandani et al. 2009; Mian and Sufi 2009).

In contrast to this extensive macroeconomic research there is a smaller, but recently growing literature studying the determinants of HEW on the household level. A microeconomic analysis is not only necessary to better understand aggregate developments, but it also takes into account that HEW has direct consequences for the withdrawing household itself. It can be used to smooth consumption, finance investments, or pay off more expensive debt, thereby allowing to adjust income and saving streams. In this sense it can be a means to better financial management and expand a household's financial scope when it would otherwise be credit constrained. Analysing the factors and motivation driving HEW is therefore essential to understand the way households benefit from accessing this important wealth component and sheds some light on potential risks arising from this type of financing. ${ }^{4}$

\footnotetext{
${ }^{1}$ Box A.1 in Appendix A defines HEW in more detail.

${ }^{2}$ According to the Dutch National Bank (DNB), HEW contributed to economic growth with 1\% in 1999 and $2000,-0.5 \%$ in 2001 and 2002 and $-0.25 \%$ in 2003 (DNB 2003).

${ }^{3}$ The major question is if spending would have occurred independently of home equity withdrawal, or if it is crowding out spending from other financing sources. Manchester and Poterba (1989) find evidence that increased access to second mortgages reduced personal savings what would point towards increased spending due to equity withdrawal, while Klyuev and Mills (2007) do not find a significant effect in the short- or long-run. ${ }^{4}$ While the focus of this study is on the economic and financial aspects of HEW, there are also implications for housing and social policy. Money that is withdrawn but not reinvested into housing could lead to 'equity leakage'. For a discussion see Smith and Searle (2008).
} 
Economic theory has highlighted different reasons why households withdraw home equity (e.g. Hurst and Stafford 2004; Angelini and Simmons 2005; Angelini 2006). It allows them to overcome negative income shocks (buffer motive), to benefit from more favourable financial conditions if it is used to refinance existing debt (financial motive), or to borrow against rising future income (life-cycle motive). Differentiating between HEW via remortgaging or via housing transactions, this study investigates how far these theoretical predictions are supported by the data.

From a probit analysis of the choice between withdrawing home equity and not altering home equity, we draw three main conclusions. First, the Dutch data do not support findings from earlier studies about the USA and the UK that home equity withdrawal is used as a financial buffer against negative income shocks. Second, financial motives seem to be important for the decision to withdraw home equity. Individuals expecting increasing mortgage interest rates in the future or having a high outstanding mortgage value are more likely to withdraw. Third, age effects turn out to be significant, as the probability of HEW increases until the mid-50s, showing that households have first to build up home equity before they are able to use it later on. The study also finds weak evidence that retirees access their home equity, but rather through remortgaging or second mortgages than by moving to cheaper accommodation.

Although withdrawers have on average higher debt ratios and find it more difficult to obtain credit, the analysis dispels some worries that HEW could pose systematic risk to the economy. It is not those households at severe financial risk which use their home equity. Neither income nor net-worth has a significant impact on the decision to withdraw, and households with very high home expenditure ratios are significantly less likely to borrow against their home equity.

The analysis also provides some preliminary insights into the impact of supply side conditions on equity withdrawal that has been widely neglected by the existing empirical literature. Results indicate that tightening credit conditions represent a significant impediment for households facing a negative income shock.

The remainder of the paper is organized as follows. Section 2 gives a short overview of theoretical models incorporating the decision to withdraw home equity and summarizes the main results of the empirical evidence so far. Section 3 describes important characteristics and developments of the Dutch housing and mortgage market, the framework in which HEW takes place. Section 4 turns to the data and econometric approach and Section 5 presents the estimation results. Section 6 concludes by summarizing the main findings of this study.

\section{Theoretical background and empirical evidence}

Recently, a few economic models on household consumption have suggested different motives driving HEW.

One reason why households might withdraw home equity is to overcome negative income shocks and to smooth consumption. In Hurst and Stafford (2004) households maximise the present value of their utility from consumption by choosing the level of consumption and liquid assets as well as mortgage borrowing, given housing equity and collateral constraints. If households face a negative income shock and have little liquid assets, the probability to refinance and access home equity increases. These in a broader sense liquidity constrained households will refinance even when interest rates are stable or rising to smooth consumption. The model also highlights a second motivation for HEW, which is refinancing an existing mortgage for a higher amount to benefit from better financing conditions in a world of low interest rates. 
This financial motive is also at the core of a model about mortgage refinancing by Angelini and Simmons (2005). Households are assumed to pay an interest rate on mortgage borrowings that differs from the one received on financial assets and they face a fixed cost when adjusting the amount borrowed. Given these assumptions, it is optimal to withdraw home equity and to invest the proceeds in financial assets when the interest earned exceeds the sum of mortgage interest rates and fixed cost. In a different framework, Angelini (2006) models the HEW decision of homeowners who cannot save and who can borrow only using home equity as collateral. Under these constraints households withdraw home equity to smooth consumption when current income is low compared to future income. This is consistent with the prediction from life-cycle models, where households borrow against home equity to bring forward consumption if they expect their future income to rise. However, lifecycle considerations also require that households inject equity into their homes until full ownership, while later on they might stop injecting and withdraw equity if they move to smaller homes. These factors make it difficult ex-ante to predict how the propensity to withdraw will look like over the life-cycle.

Households could also withdraw or inject equity for reasons other than consumption smoothing and financial efficiency. Banks et al. (2004) point out that owning a home insures against buying at higher prices in the future. ${ }^{5}$ In a multi period model they show that home equity acts as insurance against house price volatility, with owner-occupiers living in areas with volatile house prices being more reluctant to withdraw home equity for non-housing consumption. They also bring their model to the data and find supporting empirical evidence for the UK and the USA.

So far only a few studies have tried to test the relative importance of the different motivations brought up by the theoretical models. Hurst and Stafford (2004) find supporting evidence for the predictions of their theoretical model using US data for 1991-1996 from the Panel Study of Income Dynamics (PSID). A financial shock defined as an unemployment spell increased the probability of withdrawing equity for otherwise liquidity constrained households, as did a higher present value of the wealth gain from refinancing. This financial motive is also supported by Canner et al. (2002) who analyse the monthly Surveys of Consumers in 2002. Interestingly, the self-assessed likelihood of becoming unemployed was not important for the refinancing decision. While these studies focus on gross HEW, i.e. before use of funds, through refinancing, Schwartz et al. (2008) analyse net withdrawal or net injections, i.e. total injections into housing minus total amount withdrawn, in 2004 using a survey of Australian households. They are able to distinguish between HEW through refinancing and through property transactions, with the latter comprising the bulk of equity withdrawals and injections in monetary terms, and find support for life-cycle, financial and income factors driving the decision to withdraw or inject home equity.

The importance of different motives is also shown by Benito (2009), who uses information regarding gross HEW from the British Household Panel Survey (BHPS) for 1992-2003. Households are more likely to withdraw home equity if they face a negative income shock, get divorced or married, or have higher home equity. In contrast to the finding by Schwartz et al. (2008), younger households are more likely to withdraw, suggesting that for this data and definition of HEW, consumption smoothing considerations dominate among life-cycle effects.

The following study contributes to the literature in two ways. First, it provides empirical evidence on the factors driving the decision to withdraw home equity in the continental European context, looking at the Dutch housing market between 2003 and 2007. Second, it assesses which theoretical predictions about HEW are supported by the data, controlling for socio-demographic variables and households' expectations, habits, and financial risk aversion.

\footnotetext{
${ }^{5}$ Similarly, Sinai and Souleles (2005) emphasize that homeownership provides a hedge against fluctuations in housing costs. Their model does however not incorporate the decision to withdraw home equity.
} 


\section{Dutch housing market}

To understand home equity withdrawal, it has to be seen in the context of the housing and mortgage market. This section gives a short overview of the main developments in the Netherlands in recent years.

In the last decade the Dutch housing market has been one of the most dynamic in Europe, characterised by sharp house price rises in the late 1990s, innovations on the mortgage market, and increased household debt. Although the developments have been in some respect similar to other countries, they have been more pronounced, making the Netherlands an interesting case to study. The following points are important: First, house prices have risen sharply both in nominal and real terms before and around the turn of the century, with annual growth rates peaking at $18 \%$ in 2000 . Since then, growth rates have cooled down and prices have increased slightly above the inflation rate. ${ }^{6}$ The house price boom of the 1990 s can be explained by favourable cyclical conditions, low mortgage interest rates, low supply elasticity of new housing, demographic developments like immigration and the trend towards smaller households, the fiscal regime, and liberalisation, competition and innovation on the mortgage market (Van Dijkhuizen 2005). This has increased home equity and the scope of its withdrawal.

Second, due to the rise in house prices and home ownership ratio, residential property has become the most important asset of Dutch households, while mortgage debt dominates the liability side. ${ }^{7}$

Third, the outstanding amount of mortgages has increased rapidly, with the ratio of outstanding residential mortgage to GDP reaching 100\% in 2003, up from 46\% in 1994, one of the highest ratios in Europe. ${ }^{8}$ A fiscal regime that allowed full deductibility of mortgage payments at the marginal tax rate has clearly favoured this development. In an attempt to discourage excessive mortgage growth, deductibility for mortgages used for non-housing consumption or investments and second home purchases has been removed in 2001. As a further limitation, interest rate deductibility was limited to 30 years in 2002, and since 2004 homeowners moving to more expensive homes have had to use capital gains on their former homes as down payment by law. ${ }^{9}$ This might have curbed the use of HEW to finance consumption, although it remains attractive due to the usually lower level of mortgage interest rates compared to other loans.

Finally, taking out mortgages has become easier and cheaper. Average mortgage interest rates have fallen consistently over the past two decades, which can be accounted for by increased market competition, liberalisation, and the macroeconomic environment. ${ }^{10}$ The Dutch mortgage market is still dominated by banks, which in 2003 accounted for $74 \%$ of the market, but recently there has been a tendency to sell mortgages through intermediaries (Boelhouwer 2002). The typical maturity of a mortgage in the Netherlands is 30 years, with interest rates fixed for 5 to 10 years. The fiscal regime has spurred the development of new mortgage products, which maximise the fiscal deductibility of mortgage interest such as

\footnotetext{
${ }^{6}$ See Figure A.1 in Appendix A. Lately house prices started to decline due to the global economic crisis. According to the Dutch Central Bureau of Statistics (CBS) prices of existing houses sold in June 2009 were on average $3.7 \%$ lower than twelve months previously.

${ }^{7}$ Owner occupancy has gradually increased in the Netherlands from $29 \%$ in 1950 to $42 \%$ in 1980 and $55 \%$ in 2003 (see National Board of Housing, Building and Planning Sweden and Ministry for Regional Development of the Czech Republic 2005). For international evidence that borrowing for housing accounted for the bulk of the increase in household debt see Debelle (2004).

${ }^{8}$ See table A.1 in Appendix A.

${ }^{9}$ Besides fiscal deductibility of mortage interest rates, capital gains on own property are not subject to taxation. Only the imputed market based rental value of property is added to taxable income and local property tax has to be paid. Finally, own property movers have to pay a transfer tax of $6 \%$ of the purchase price.

${ }^{10}$ See Figure A.2 in Appendix A.
} 
interest-only mortgages, while traditional annuity and linear mortgages have lost ground. Furthermore, the popularity of savings and investment mortgages as well as endowment mortgages has increased. The latter allows borrowers to get a new loan on (part of) the amount that already has been paid off during the term of the mortgage, facilitating home equity withdrawal.

When granting mortgage credits, lenders assess the repayment capacity and reliability of the client together with the collateral. In the Netherlands, the main criterion is the housing expenditure ratio that is the ratio between mortgage expenses, which includes interest, premiums and repayments, and household income. Up to a value of $25 \%$ housing is considered affordable, between 25 and $35 \%$ households are able to afford their housing under normal circumstances, but adverse financial shocks can represent a problem, and ratios above $35 \%$ indicate that homeownership is likely to be unsustainable in the future (Dol and Neuteboom 2008). In this regard, the National Mortgage Guarantee (NHG) plays a specific role. For mortgages sold under its norm, the NHG will cover the mortgage payments to the bank should structural repayment problems arise. ${ }^{11}$ Borrowers using this scheme have to pay a one-time upfront fee of $0.4 \%$ of the outstanding mortgage and receive a limited interest rate discount (up to $0.6 \%$ ) on the current rate. Furthermore, they can apply for a top-mortgage including the transaction costs, while the lender has the advantage that mortgages covered by the NHG enter the solvency requirements with a risk weighting of zero (Dol and Neuteboom 2008, Van Dijkhuizen 2005; Boelhouwer 2002). In general, mortgages can be refinanced at the cost of a penalty, but in practice prepayment is likely to result in additional costs for lenders, because only a proportion of yield maintenance fees can be recovered (M. O. Wyman 2003). ${ }^{12}$

\section{Data and econometric approach}

\section{(a) Data}

The data used in this study come from survey waves from 2002 to 2008 of the Dutch National Bank Household Survey (DHS). It represents a rich panel dataset, providing information regarding gross $\mathrm{HEW}$, mortgages and a household's economic and financial situation in general. Socio-demographic characteristics and expectations about price and interest rate developments are retrieved as well. The survey collects information about two different channels of HEW. First, it asks if during a certain year home equity was withdrawn by taking out an additional mortgage or by remortgaging with a higher principal without moving home. ${ }^{13}$ It also contains information concerning the amount withdrawn and its use, although for the latter this is not done separately for each year. Second, households which have recently moved are asked whether they withdrew equity by moving to a cheaper accommodation or by taking out a higher mortgage than necessary for buying the house.

In contrast to Schwartz et al. (2008), but similar to Benito (2009) and Hurst and Stafford (2004), this study is about gross HEW, since all or part of the proceeds can be reinvested into the housing sector. Given that part of the effect of equity withdrawal on the economy is due to investment in the housing sector, this does not question the relevance of aggregate effects.

\footnotetext{
${ }^{11}$ In the Netherlands, mortgage holders also have full recourse against borrowers who have defaulted on mortgage payments. Moreover, there is a Mortgage Code of Conduct that should prevent lenders from granting risky mortgages (see Van Dijkhuizen 2005).

${ }^{12}$ In addition, the Dutch law allows $15 \%$ of a mortgage loan to be repaid without charge each year, and prepayment when moving homes is also not charged.

${ }^{13}$ A detailed description of the variable measuring HEW and its usage in this study is given in Appendix B.
} 
The DHS consists of approx. 1800 households per survey year, of which around 900 households hold a mortgage and state whether they have withdrawn home equity without moving (labelled as non-transactors in Table 1). On average 24 households have moved during a year and have indicated whether they used the surplus value i.e. selling value minus total sum of the mortgage (referred to as transactors). ${ }^{14}$ Due to the availability of important explanatory variables, the econometric analysis is restricted to a sample covering the years 2004 to 2007, but the proportions of withdrawers are similar to the full DHS sample.

Table 1: Summary statistics DHS and sample

\begin{tabular}{|c|c|c|c|c|c|c|c|c|}
\hline \multicolumn{9}{|l|}{ DHS } \\
\hline \multirow[b]{2}{*}{2002} & \multicolumn{2}{|l|}{$\begin{array}{r}\text { individuals } \\
\text { (total) } \\
\end{array}$} & non-transactors & \multicolumn{2}{|c|}{$\begin{array}{c}\text { withdrawers } \\
\text { (without moving) }\end{array}$} & \multirow[t]{2}{*}{ transactors } & \multicolumn{2}{|c|}{$\begin{array}{c}\text { withdrawers } \\
\text { (when moving) }\end{array}$} \\
\hline & 4772 & 1943 & 857 & 53 & $6.2 \%$ & & 4 & $25.0 \%$ \\
\hline 2003 & 4627 & 1912 & 979 & 57 & $5.8 \%$ & 17 & 9 & $52.9 \%$ \\
\hline 2004 & 4877 & 1993 & 1048 & 68 & $6.5 \%$ & 27 & 10 & $37.0 \%$ \\
\hline 2005 & 4726 & 1936 & 986 & 56 & $5.7 \%$ & 42 & 10 & $23.8 \%$ \\
\hline 2006 & 4387 & 1776 & 913 & 55 & $6.0 \%$ & 28 & 12 & $42.9 \%$ \\
\hline 2007 & 4070 & 1660 & 877 & 63 & $7.2 \%$ & 13 & 5 & $38.5 \%$ \\
\hline total & $\begin{array}{l}\text { Observations } \\
\text { (Households) } \\
\end{array}$ & $\begin{array}{r}11220 \\
(3615) \\
\end{array}$ & $\begin{array}{r}5660 \\
(1538) \\
\end{array}$ & $\begin{array}{r}352 \\
(246) \\
\end{array}$ & $6.2 \%$ & $\begin{array}{r}143 \\
(128) \\
\end{array}$ & $\begin{array}{r}50 \\
(49) \\
\end{array}$ & $35.0 \%$ \\
\hline \multicolumn{9}{|l|}{ Sample } \\
\hline & & & non-transactors & \multicolumn{2}{|c|}{$\begin{array}{c}\text { withdrawers } \\
\text { (without moving) }\end{array}$} & transactors & \multicolumn{2}{|c|}{$\begin{array}{c}\text { withdrawers } \\
\text { (when moving) }\end{array}$} \\
\hline \multicolumn{9}{|l|}{2002} \\
\hline \multicolumn{9}{|l|}{2003} \\
\hline 2004 & & & 204 & 16 & $7.8 \%$ & 15 & 6 & $40.0 \%$ \\
\hline 2005 & & & 218 & 22 & $10.1 \%$ & 24 & 7 & $29.2 \%$ \\
\hline 2006 & & & 227 & 14 & $6.2 \%$ & 11 & 2 & $18.2 \%$ \\
\hline 2007 & & & 243 & 17 & $7.0 \%$ & 7 & 2 & $28.6 \%$ \\
\hline total & $\begin{array}{l}\text { Observations } \\
\text { (Households) }\end{array}$ & & $\begin{array}{r}892 \\
(492)\end{array}$ & $\begin{array}{r}69 \\
(61)\end{array}$ & $7.7 \%$ & $\begin{array}{r}57 \\
(55)\end{array}$ & $\begin{array}{r}17 \\
(17)\end{array}$ & $29.8 \%$ \\
\hline
\end{tabular}

Notes: Numbers refer to the year in which HEW is observed, but were assessed in the survey of the following year. E.g. 2007 numbers come from the DHS survey 2008, but examine HEW in 2007.

The explanatory variables can be broadly classified according to the different motives driving equity withdrawal. ${ }^{15}$ These are (i) overcoming negative income shocks, (ii) financial motives including financial cost minimisation and portfolio diversification, (iii) direct wealth effects, (iv) consumption smoothing over the life-cycle, and (v) house price insurance. A dummy variable measuring whether the income of an individual is 'unusually low' compared to a 'regular' year captures a negative income shock. Similarly, a negative health shock and dummies for marriage or divorce try to assess the importance of equity withdrawal as a financial buffer. In this regard, liquidity constraints might play a role (see e.g. Hurst and Stafford 2004), which are proxied by the households self-assessed possibility to 'easily get a loan', the ability to manage on the household income and the availability of liquid assets.

Variables accounting for the financial efficiency motive include an estimate of the income tax rate and the lagged value of the outstanding mortgages. Households paying a higher tax rate and having more mortgage debt should benefit most from the tax deductibility scheme and more favourable financing conditions. ${ }^{16}$

\footnotetext{
${ }^{14}$ This labelling follows Schwartz et al. (2008).

${ }_{16}^{15}$ Appendix $\mathrm{C}$ contains the full list of explanatory variables and their definition.

16 This holds if households refinance their existing mortgages at a lower interest rate while at the same time increasing the amount borrowed or if part of the equity withdrawn is used to pay off more expensive debt. A basic regression of a dummy variable measuring whether the proceeds from HEW are used to repay existing debt on the tax rate and the outstanding mortgage value delivers some supporting evidence of the validity of these proxies.
} 
Another reason why households might withdraw equity is to rebalance their portfolio by shifting housing wealth towards other assets. I try to proxy this effect with a self-assessed measure of the increase in the value of the home since it has been bought and with the increase in the last year. These are however imperfect proxies since they might also capture direct wealth effects from increased house prices, which lead to higher consumption financed by HEW. Life-cycle effects are accounted for by the age of the household, a dummy variable indicating whether the individual is retired, and expectations about the future financial situation of the household. Finally, the standard deviation of regional house prices over the last five years is used to assess house price uncertainty and the insurance role of home equity. This measure is similar to the one used by Benito (2009) and Banks et al. (2004), but relies on aggregated data from Statistics Netherlands rather than on the survey data.

In addition, control variables for mortgage and demographic characteristics, education, time and geographical effects are included. Expectations about future mortgage interest rates, house price developments, and changes in the tax deductibility scheme complete the set of explanatory variables.

\section{(b) Descriptive Statistics}

This Section presents some descriptive statistics separately for households stating whether they were withdrawing home equity without moving (non-transactors), and households having recently moved and stating whether they were withdrawing home equity when moving (transactors).

\section{Non-transactors}

According to the DHS, the share of mortgage holders withdrawing home equity without moving fluctuated around 6 to $7 \%$ between 2002 and 2007, as shown by Figure 1. ${ }^{17}$

Figure 1: Share of mortgage holders withdrawing home equity

Source: DHS.

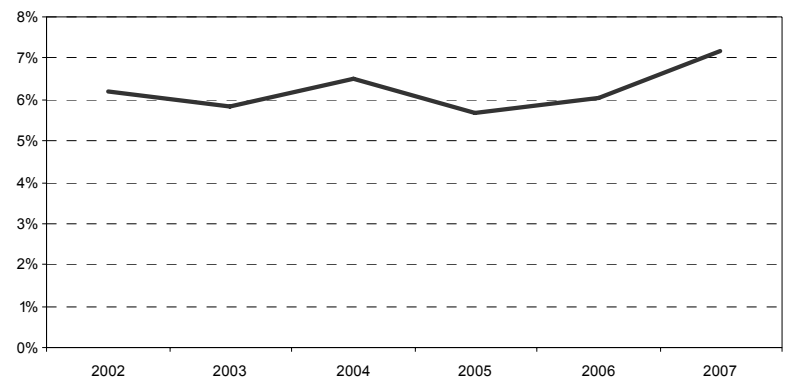

While this proportion remained rather stable, the mean amount withdrawn changed somewhat more over time, with an average value of $29,422 €$ over 2002 to 2007 (in 2000 prices). ${ }^{18}$ This is a slightly higher value than the $25,615 €$ British households withdrew on

\footnotetext{
${ }^{17}$ Benito (2009) found for the UK that around 10\% of all homeowners withdrew home equity in 2003 (taking transactors and non-transactors together), whereas according to Schwartz et al. (2008) 7.2\% of all Australian households withdrew equity in 2005 without property transactions and 4.4\% through transactions (net HEW).

${ }^{18}$ See Figure A.3 in Appendix A. HEW as a share of GDP is calculated by multiplying the mean amount withdrawn by the share of withdrawers compared to all households in the survey and the number of households in the Netherlands.
} 
average during 1992 to 2003 according to Benito (2009). ${ }^{19}$ Translated into aggregate figures, gross HEW by non-transactors represented between 1 and 2\% of GDP in the Netherlands and has therefore a potentially significant impact on the economy.

Panel A in Figure 2 shows that most of the households use all or part of the equity withdrawn for property improvements $(77 \%)$ and only a small fraction also or exclusively for spending on durable goods $(13 \%)$ and electronics $(5 \%)$ or for paying off other debt $(11 \%)$. The usage in monetary terms reflects this pattern as displayed in panel B. The bulk of the money is reinvested into the housing sector $(56 \%)$ and only a small part used to purchase durables $(6.5 \%)$ and electronics $(1.7 \%)$ or to pay off existing debt $(7.3 \%)$. These figures show that net home equity withdrawal masks a substantial amount of withdrawals reinvested into housing, which is also confirmed by evidence from the USA (Canner et al. 2002) and the UK (Benito 2009) and suggests that only a small part of the growth in consumption in recent years may be attributed to HEW.

Figure 2: Use of home equity withdrawn over 2002 to 2007 (non-transactors)

Panel A Shares (multiple answers possible)

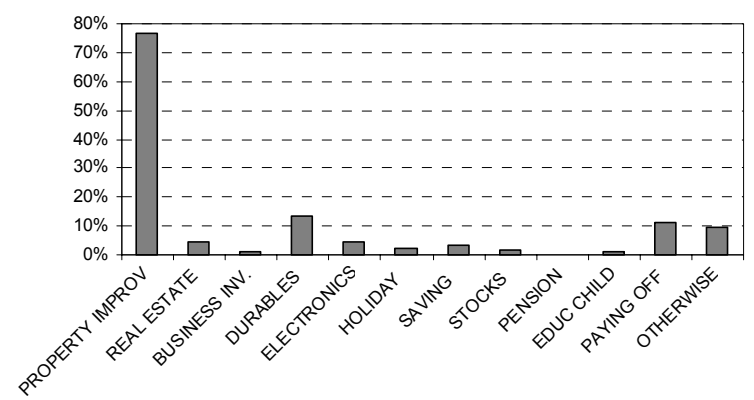

Panel B Shares in monetary terms

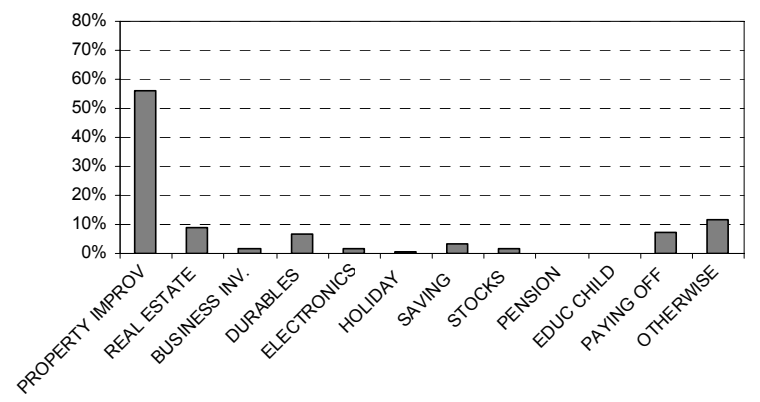

Notes: Figure shows the percentage of households that used (part) of the money withdrawn for a certain purpose (panel A) and the percentage of the monetary value going to it (panel B). Property Improv. stands for Property Improvement and Business Inv. for Business Investment. Source: DHS.

From Table 2 we get some first descriptive information on the characteristics of withdrawers vis-à-vis non-withdrawers. On average, both groups are affected equally by income shocks or other shocks with potential financial impacts, as revealed by t-tests of the means. However, withdrawers seem to be significantly more likely to be credit constrained and to have debts, as well as having on average more outstanding mortgage debt on the home they are living in and a lower household income than non-withdrawers. Furthermore, the proportion of endowment mortgages among the mortgages with the highest outstanding value is higher for withdrawers, making it easier to access home equity. ${ }^{20}$

\footnotetext{
${ }^{19} 25,615 €$ are the $15,612 £$ (in 2000 prices) mentioned by Benito (2009) using the average exchange rate during 2000. This is even more remarkable when taking into account that the British figure includes transactors and non-transactors, the former usually being regarded as withdrawing more equity. Schwartz et al. (2008) found that non-transactors withdrew on average 20,000 AU\$ in 2005, compared to an average of 80,000 AU\$ withdrawn by transactors (approx. 6,643€ and 26,573€ respectively, using the average exchange rate during 2000 and in 2000 prices; numbers refer to net HEW).

${ }^{20}$ Since it cannot be exactly assessed by the DHS which mortgage has been refinanced with a higher value or whether a new mortgage has been taken out, the following approach has been adopted: mortgage variables refer to the mortgage with the highest value outstanding in $t-1$, except for the amount outstanding, which is the sum over all mortgages held by a household in $t-1$. Although any approach trying to tackle this problem has its drawbacks, this one has the advantage of being consistent with the financial motive, which predicts that the financial gain is bigger if a higher value is refinanced.
} 
Table 2: Summary statistics (non-transactors)

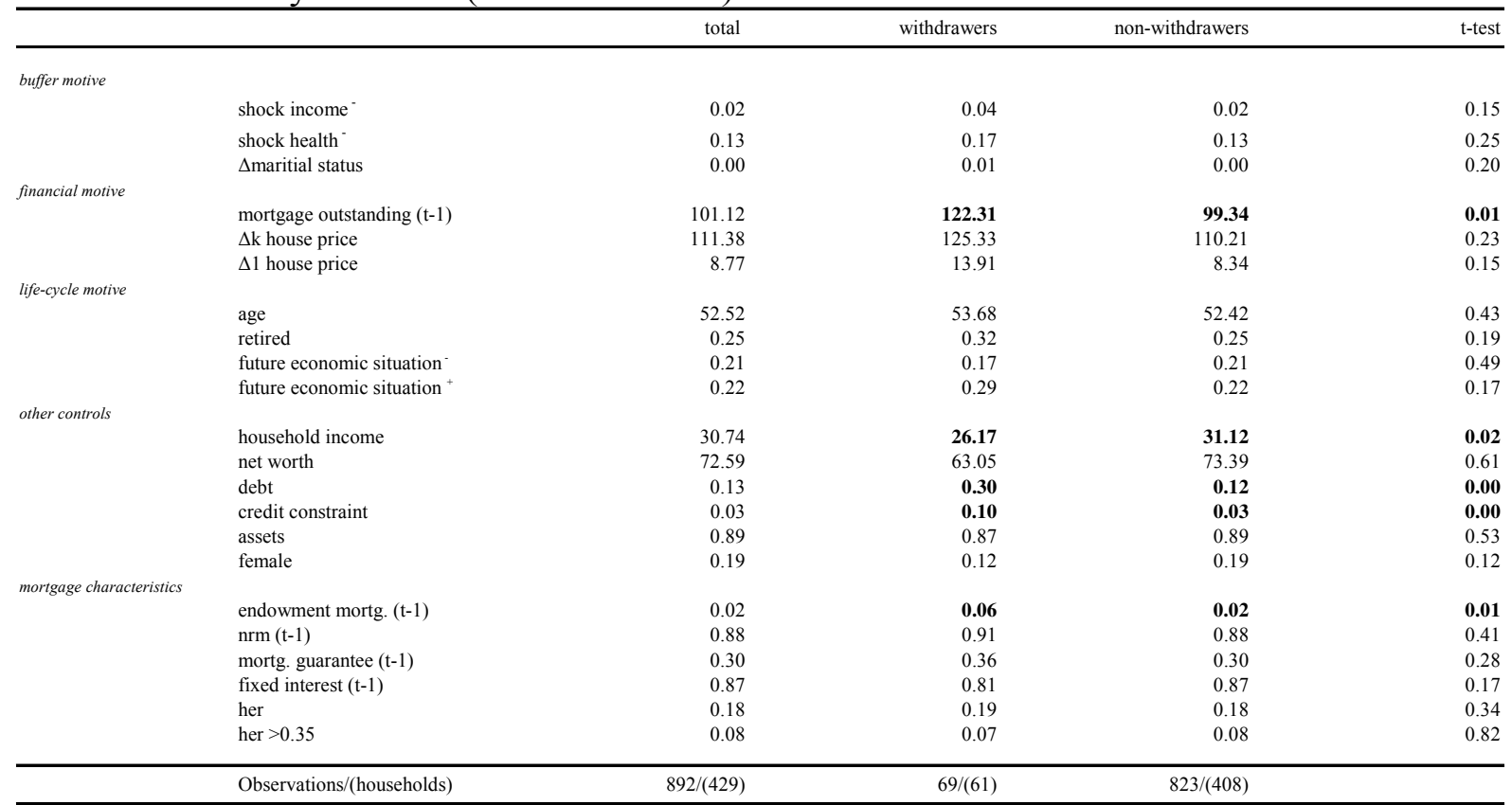

Notes: Table shows sample means (proportions for dummy variables) and p-values for t-tests; mean values significantly different at the 10\% level between the two groups are in boldface. Source: DHS 2004-2007.

\section{Transactors}

HEW is much more frequent among transactors than among non-transactors as shown by Figure 3. On average, 37\% of all transactors withdrew home equity over 2002 to 2007, although there are significant differences from year to year. With $42,397 €$ (in 2000 prices) the mean value withdrawn is significantly higher than the one for non-transactors $(29,422 €)$, which is in line with previous studies of Schwartz et al. (2008), Benito and Power (2004), and Holmans (2001). By number, however, most of the withdrawals are accounted for by nontransactors, which is also reflected in the aggregate. Home equity withdrawn by transactors was between 0.1 and $0.5 \%$ of GDP in the period analysed and is thus a smaller amount than HEW by transactors. ${ }^{21}$

The spending pattern is similar to non-transactors (see Figure 4). The majority of households uses the equity withdrawn for property improvements $(68 \%)$ and only few households also or exclusively for the purchase of durables $(6 \%)$, electronics $(8 \%)$ or the redemption of other debt (16\%). A substantial share of withdrawers $(38 \%)$ also uses the proceeds to cover additional moving costs such as taxes and broker fees. ${ }^{22}$

\footnotetext{
${ }^{21}$ See Figure A.4 in Appendix A. This finding is in contrast to Schwartz et al. 2008 who found that transactors accounted for $72 \%$ of the overall value of (net) withdrawals. Besides the different concepts of gross and net HEW, DHS data do not cover the sale of properties resulting from the death of an owner, a potentially significant component. Differences between Australia and the Netherlands both in the mean amounts withdrawn and the number of property transactions might also account for the disparity of the data.

${ }^{22}$ For transactors, the DHS only provides information about the usage of the equity withdrawn, but not on the monetary value going to each category.
} 
Figure 3: Share of HEW through transaction as a fraction of total transactions

Source: DHS.

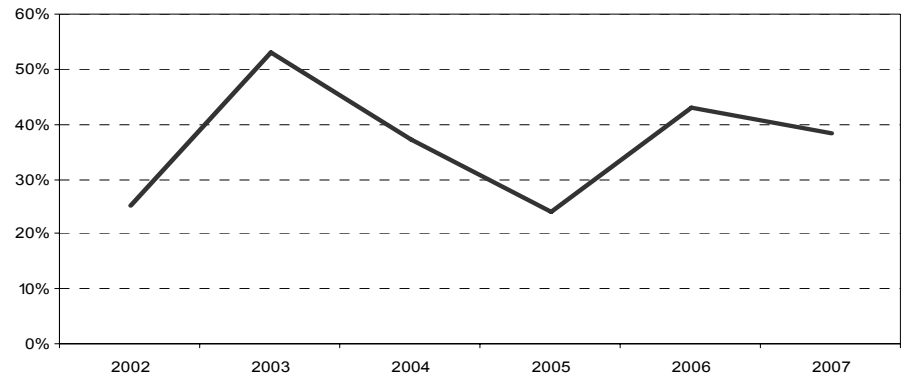

Figure 4: HEW through transaction: use of surplus value (multiple answers) 2002-2007

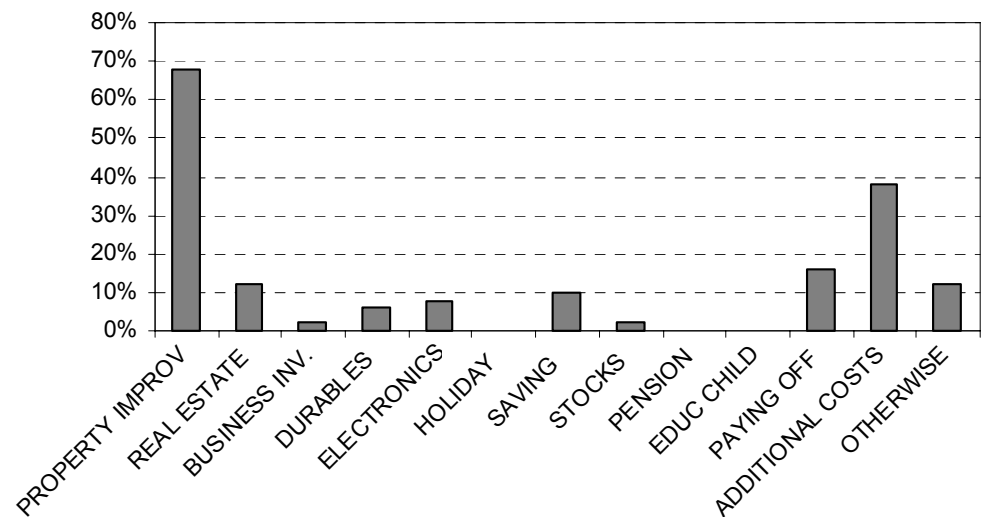

Notes: Figure shows the percentage of households that used (part) of the money withdrawn for a certain purpose. Property Improv. stands for Property Improvement and Business Inv. for Business Investment. Source: DHS.

A mean comparison of some key variables between withdrawers and non-withdrawers gives preliminary insight into the motivation behind HEW. Although one should read the results with caution due to the small sample size, a few patterns emerge. Table 3 shows that withdrawers are more likely to have experienced a negative income shock, to have children, and to have not attended university. The proportion of retirees is lower among withdrawers, and the net worth of withdrawers compared to non-withdrawers is on average lower (not statistically significant).

Table 3: Summary statistics (transactors)

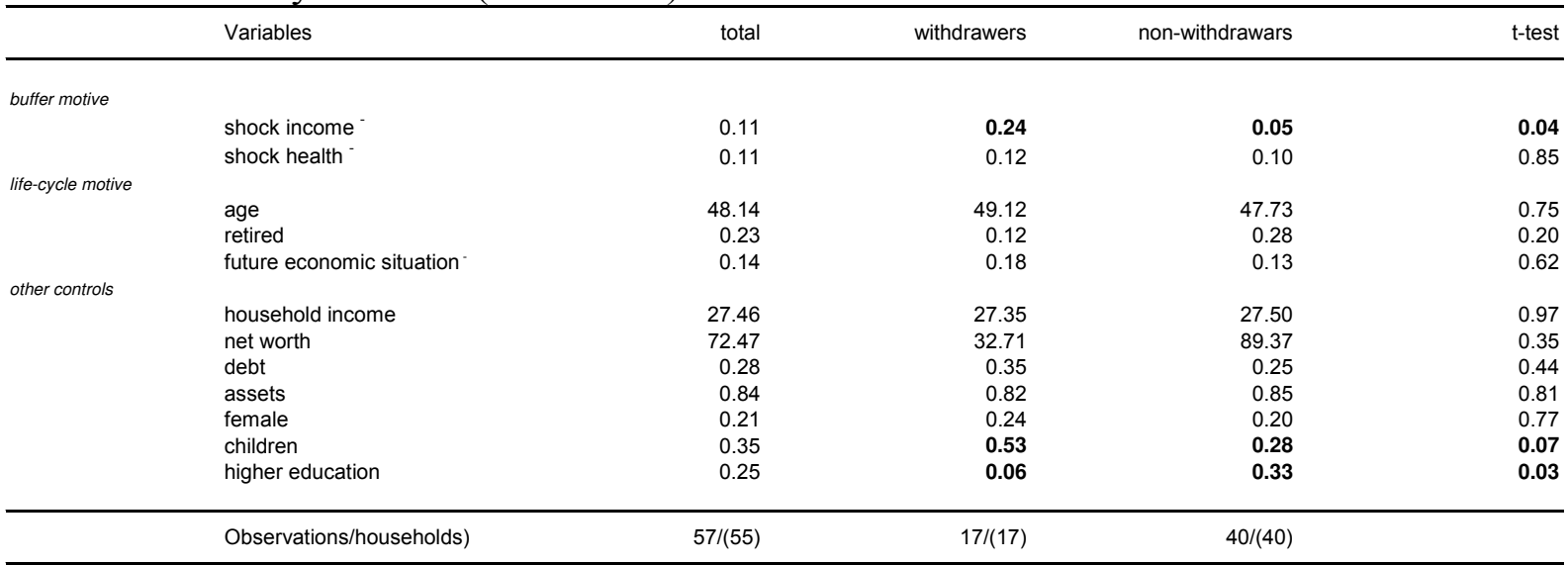

Notes: Table shows sample means (proportions for dummy variables) and p-values for t-tests; mean values significantly different at the 10\% level between the two groups are in boldface. Source: DHS 2004-2007. 
For a more thorough understanding of the variables driving HEW, an econometric analysis is carried out in the following. Due to data availability it is restricted to the period 2004 to 2007.

\section{(c) Econometric approach}

A probit model for the decision to withdraw home equity is estimated separately for households who have not moved and might have withdrawn equity by taking out a second mortgage or refinancing with a higher principal (non-transactors) and for households who have recently moved and might have used the surplus value from selling the house (transactors). Although in principle HEW is expected to be driven by the same motives independently of the channel used, a separate analysis for transactors is justified by the fact that the decision to withdraw home equity when moving is more involved and likely to differ from HEW without moving. Findings by Schwartz et al. (2008) and the descriptive data analysis in Section 4 (b) point in this direction. The probability that a household has withdrawn is given by

(1) $\mathrm{P}(\mathrm{y}=1 \mid x, z, d)=\Phi(\alpha+x \beta+z \delta+d \gamma)$

and the estimated equation can be formalised by

(2) $y_{i t}=1\left[\alpha+X_{i t}^{\prime} \beta+Z_{i t-1}^{\prime} \delta+D_{t} \gamma+\varepsilon_{i t}>0\right]$

with $X$ being a vector of contemporaneous covariates, $Z$ a vector of lagged covariates, $D$ a vector of year dummies controlling for time effects, $i=1,2, \ldots, N$ an index for households and $t=2004, \ldots, 2007$ for years. The random error $\varepsilon$ is assumed to be normally distributed with $\mu=0$ and $\sigma=1$. Equation (2) is estimated by maximum likelihood with standard errors clustered at the individual level. ${ }^{23}$ This pooled probit approach implicitly assumes that unobserved effects are absent and all individual heterogeneity is accounted for by the covariates. $^{24}$

\section{Estimation Results}

This section first presents the results for non-transactors, followed by a discussion of the findings regarding transactors. For the former, separate estimations are carried out for the year 2007 and the pooled sample of 2004 to 2007 to test the stability of the estimates. This approach also takes into account that the DHS asks explicitly for information about HEW in 2007, whereas for the pooled sample an indicator variable has to be constructed (see Appendix B). Estimates for transactors are only based on the pooled sample.

\footnotetext{
${ }^{23}$ Since the DHS is a panel, households appear more than one time in the sample. Clustered standard errors allow for serial correlation at the individual level and are robust to some forms of misspecification of the likelihood function, where the maximum is still at the same point as for the true likelihood function.

${ }^{24}$ Unobserved time constant random effects turn out to be insignificant when estimating a random effects (RE) probit model (results are available from the author). Note, however, that the signs of the coefficients obtained by pooled probit estimation are correct even in the presence of RE, since average partial effects are estimated consistently (see Wooldridge 2002).
} 
The decision to withdraw equity in 2007 is modelled by a basic specification capturing the different motives that might drive HEW (column 1 in Table 4) and a more general model additionally controlling for expectations and personal characteristics (column 2).

It is first investigated whether withdrawing home equity acts as financial buffer. While this is supported by data for the USA (Hurst and Stafford 2004) and the UK (Benito 2009), there is little evidence for the Netherlands. A negative income shock increases the propensity to withdraw in the basic model, but this effect becomes insignificant when controlling for additional variables. For 2007 it seems rather to be the case that households use their home equity when expecting a deterioration of their future economic situation. At first sight this it at odds with the idea of precautionary saving, but can be reconciled with it if the amount withdrawn is saved, used for measures that buffer expected negative events in the future or reinvested into housing so that net HEW is non-negative.

Households also seem not be driven by financial efficiency considerations in 2007. Both the tax rate and the outstanding mortgage amount in $t-1$ do not enter the model significantly. In contrast, the house price appreciation in the last year is associated with a positive and significant coefficient, meaning that households take advantage of recent capital gains. Part of this might be related to portfolio rebalancing in a broader sense, where households try to avoid an excessive accumulation of wealth in one asset class.

As a further result, the data support life-cycle effects. ${ }^{25}$ The probability of withdrawing equity increases until around the age of 55 and decreases afterwards. This confirms findings by Schwartz et al. (2008) and is consistent with the view that households first have to build up housing equity in early years that can be used later on.

An aspect that has received little attention by previous studies is the characteristics of mortgages taken out prior to HEW. This analysis looks at the mortgage with the highest outstanding value in $t-1$, making it a plausible candidate for refinancing. One would expect insignificant coefficients pertaining to this mortgage should the approach not reflect reality. However, results show that holding an endowment mortgage is an important driver of withdrawing home equity, as it facilitates borrowing, and being guaranteed by the National Mortgage Guarantee works in the same direction. ${ }^{26}$ As mentioned earlier, the latter not only reduces credit risk, but also offers advantages in form of lower liquidity requirements to the lending institution.

In addition, expectations and personal attitudes play a role, as shown by the extended model in column (2). Individuals that already planned to withdraw home equity in $t-1$ are more likely to do so in $t$, as well as individuals expecting a rise in mortgage interest rates. In contrast, HEW occurs less frequently if one thinks in a longer time dimension when deciding about what part of the income to spend or to save, or if one plans to move in the foreseeable future. These factors do not only deliver additional insight into the determinants of HEW, but by controlling for them there is less risk of an omitted variable bias that would arise if one of the explanatory variables like mortgage characteristics were correlated with the error term in equation (2).

To see whether these results hold for a larger sample and a longer time period, the model is re-estimated for a pooled sample covering the period 2004 to 2007. Again, a baseline

\footnotetext{
${ }^{25}$ As Schwartz et al. (2008) point-out, it is difficult to disentangle age from cohort effects if $\mathrm{T}$ is small and impossible in cross-Sections. However, in contrast to life-cycle effects there is no obvious reason why there could be cohort effects, and even if there were some, it seems plausible that the former would prevail.

${ }^{26}$ The concept of an endowment mortgage is related to an open end home equity loan or home equity line of credit, where the borrower can choose when and how often to borrow against the equity in the property.
} 
specification (column 3) is compared to extended models (column 4 and 5). ${ }^{27}$ While the analysis confirms most of the previous findings, there are some important differences.

First, the effects of a negative income shock or of an expected worsening of economic conditions are no longer significant, questioning the hypothesis that HEW acts as a financial buffer for Dutch households. There is also little evidence that an improved economic situation expected in the future triggers HEW today. The coefficient carries a positive sign as predicted by theories of consumption smoothing, but it is no different from 0 at common confidence levels.

Second, withdrawing home equity is tied to financial efficiency considerations over the four year period: the higher the outstanding mortgage value is, the more important the potential financial gain from refinancing and the higher the propensity to withdraw equity.

Third, changes in the house price are on average over the four years less important, being only significant at the $20 \%$ level (column 4 and 5), indicating that portfolio rebalancing considerations are of minor importance. In contrast, there is strong evidence that loan constrained or indebted households are more prone to withdraw. This supports the idea that it is mainly the collateral channel through which HEW affects the economy (see Buiter 2008; Iacoviello 2005), but does not imply that it is households at financial risk who make use of their home equity. Although withdrawers are on average less risk averse in financial matters, as they do not regard investments in shares as too risky (see variable financial risk aversion), neither household income nor net worth seem an important driving factor. In addition, individuals liking to spend all their income immediately (spending) are significantly less likely to withdraw (column 4 and 5), and a higher proportion of withdrawers state that they have a good knowledge of financial matters (financial knowledge). Withdrawers are also less likely to have a home expenditure ratio (her) above 0.35 which is an important risk criterion used by lending institutions. $^{28}$

In concurrence with the analysis of the survey of the year 2007, the pooled sample confirms the importance of mortgage characteristics, interest expectations, and life-cycle effects for the decision to withdraw home equity. The propensity to withdraw equity increases until the mid-50s and decreases afterwards, but there is some evidence that this effect is offset for retirees, although only at the $20 \%$ level (column 4 and 5). This would in principle be in line with life-cycle models predicting elderly people to decumulate wealth, and with the finding by Chiuri and Jappelli (2008) that the degree of mortgage market regulation is negatively correlated with the homeownership ratio among the elderly. ${ }^{29}$ In countries with strongly regulated markets, ownership ratios start falling after the age of 70 , possibly reflecting the desire or need to access home equity, while this effect is much weaker where mortgage markets are highly developed as in the Netherlands. The possibility of overmortgaging, remortgaging, taking out a second mortgage, or trading down allows homeowners to access home equity without moving into rental accommodation. ${ }^{30}$

The pooled sample also enables to assess the relative importance of home equity as insurance against rising house prices. While Banks et al. (2004) find supporting evidence in data for the USA and the UK, and Benito (2009) gets mixed results from the British BHPS,

\footnotetext{
${ }^{27}$ Table D.1 in Appendix D shows average partial effects (APE) for all five model specifications.

${ }^{28}$ This suggests that the reality in the Netherlands is different from the US, where Mian and Sufi (2009) find that homeowners with high credit card utilisation rates and low credit scores had the strongest tendency to borrow against increases in home equity during the house price boom, but experienced also the highest default rates after 2006. In the Netherlands there is no subprime segment comparable to the US mortgage market and stress tests indicate that the risks arising from a substantial correction in the housing market remain limited (DNB 2008).

${ }^{29}$ This analysis does not, however, tell us what the withdrawn equity is used for. Should all the proceeds be reinvested into housing or saved, there would be no reduction in wealth.

30 'Trading down' means that one moves to a cheaper property, but reduces the mortgage by less, so that the difference between selling price of the old home and purchase price of the new home on the one side, and the reduction in the amount borrowed on the other side, is positive.
} 
results from the specifications in column (4) and (5) show no significant effect. Regional house price volatility, measured as the standard deviation over the five years preceding the survey year, does not seem to influence the decision to withdraw when controlling for other regional effects. This might partly explain the contradicting results in Benito (2009), where regional house price volatility seems to matter but becomes insignificant when measured at the district level, and questions the hypothesis of HEW contrasting the insurance motive of owning a house. ${ }^{31}$

Finally, the analysis tries to give an intuition of how the supply side affects HEW. Previous empirical analyses concentrated on the demand side, abstracting from any changes on the supply side that might directly affect the decision to withdraw equity. Column (5) includes three variables capturing supply effects: a measure for the change in credit standards for loans for house purchase, for the change in credit standards for consumer credit and other loans, as well as an interaction term between the latter and the dummy for a negative income shock. ${ }^{32}$ Aggregate data show that demand for loans and credit standards are negatively correlated and therefore we would also expect to find a negative effect of tightening credit standards on the individual propensity to withdraw in the DHS data. ${ }^{33}$ For interpreting the results it is important to note that these credit standards refer to the purpose of the loan, i.e. mortgages used for consumption or education expenditure are affected by 'credit standards for consumer credit and other loans' and only mortgages used for investing in housing, including building and home improvements, are affected by 'credit standards for house purchases'. ${ }^{34}$ Consistent with the expectation, all three coefficients carry a negative sign, but only the interaction term is significant at the 5\% level. This means that credit standards do not seem to influence equity withdrawal on average, but they become important for households facing a negative income shock. Since it is plausible that these households would spend the equity withdrawn on consumer goods or for other purposes rather than reinvesting it into housing, the relevant credit standards are the ones for 'consumer credit and other loans'. When they are tightened, it becomes more difficult to remortgage or to take out a second mortgage if the income stream is adversely affected. This indicates the importance of also taking into account supply side conditions when trying to understand the factors driving equity withdrawal. Results have, however, to be interpreted with caution, since the yearly changes in credit standards could also pick up other time effects, although year dummies in column (3) and (4) are not significant (not shown).

As robustness check specification (4) is re-estimated after removing potential outliers from the sample (see Appendix E). This analysis confirms the main results from the full sample.

\footnotetext{
${ }^{31}$ House price volatility gets negatively significant at the $20 \%$ level in column (4) and (5) when there a no controls for constant regional effects.

${ }^{32}$ Data on changes in credit standards come from the Dutch part of ECB's Bank Lending Survey for the Euro area. The yearly figure used in the analysis is an average of the monthly values referring to the past quarter.

${ }^{33}$ See Figure A.5 and A.6 in Appendix A.

${ }^{34}$ See ECB (2001) p. 27 for details.
} 
Table 4: Probit models for the probability of withdrawing home equity (non-transactors)

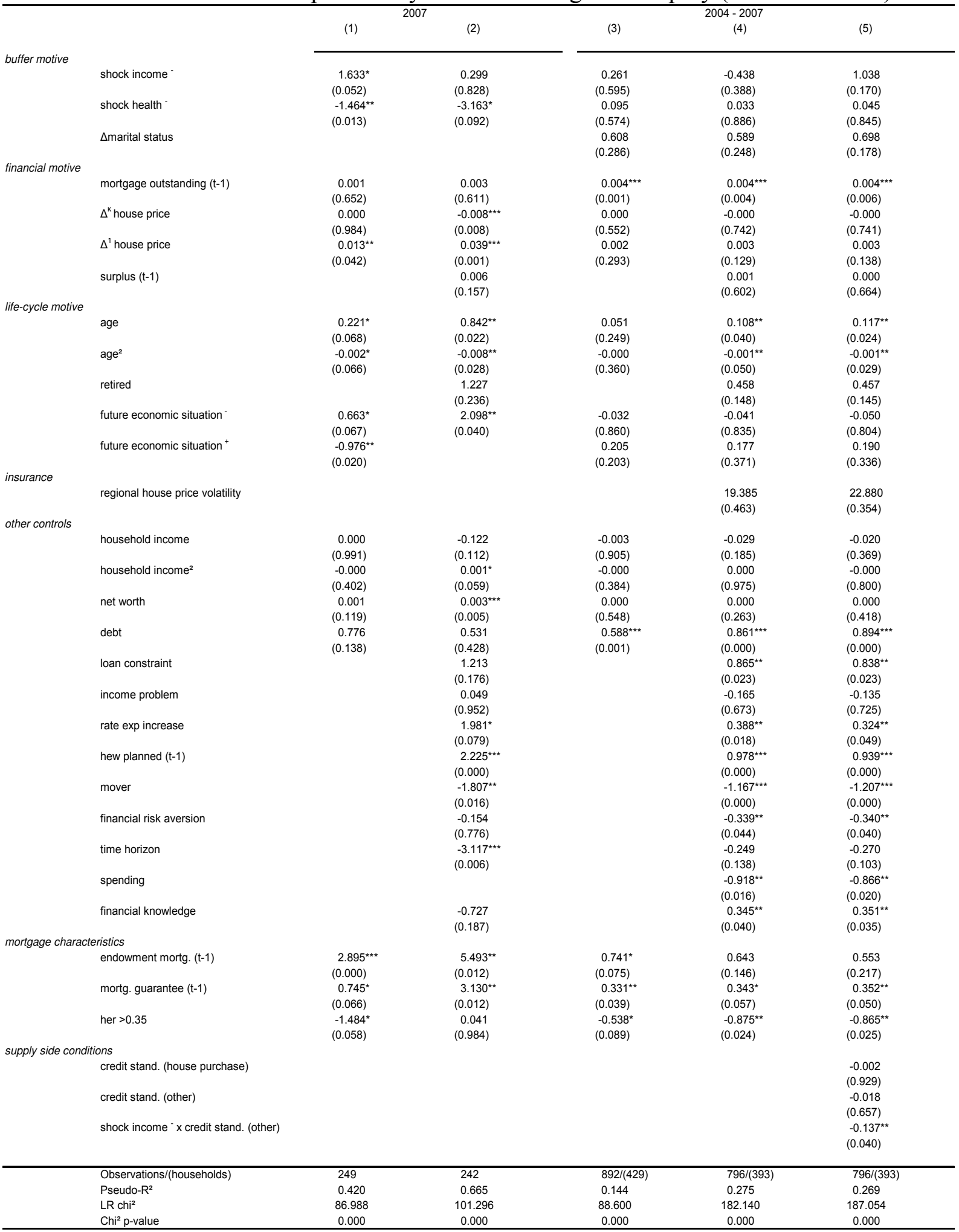

Notes: Probit coefficient estimates (p-values in parenthesis). Standard errors are clustered at the individual level. Coefficients significantly different from zero at the $10 \%, 5 \%$ and $1 \%$ level are indicated with $*$, ** and *** respectively. Pseudo $R^{2}$ refers to Mc Fadden's $\mathrm{R}^{2}$, which is defined as $1-\mathrm{L}_{1} / \mathrm{L}_{0}$ with $L_{l}$ being the log-likelihood of the full model and $L_{0}$ being the likelihood of the "constant only" model. $L R c h i^{2}$ is the test that at least one of the predictors' regression coefficients is not equal to zero. Dummies for regional and year effects (the latter are not included in specification (5)) as well as further control variables are not shown. Appendix C contains the full list of explanatory variables. 


\section{Transactors}

For comparison reasons also HEW by transactors is investigated. Due to the restricted sample size only preliminary evidence can be given, and it is not possible to control for effects pertaining to the decision to move. ${ }^{35}$ Bearing these caveats in mind, two probit models are estimated as shown by columns (1) and (2) in Table $5 .^{36}$

Table 5: Probit models for the probability of withdrawing home equity (transactors)

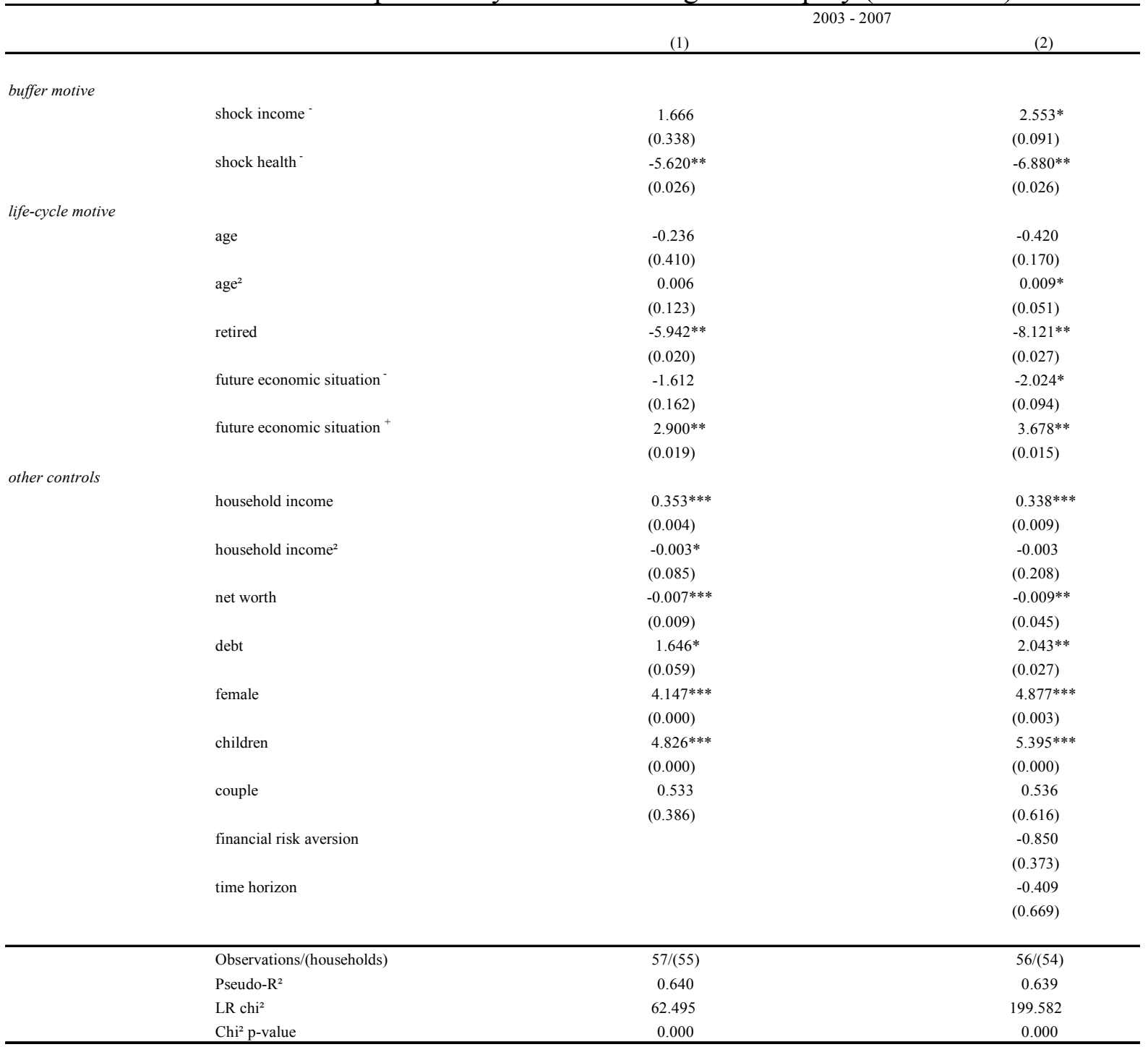

Notes: Probit coefficient estimates (p-values in parenthesis). Standard errors are clustered at the individual level. Coefficients significantly different from zero at the $10 \%, 5 \%$ and $1 \%$ level are indicated with $*, * *$ and $* * *$ respectively. Pseudo $R^{2}$ refers to Mc Fadden's $\mathrm{R}^{2}$, which is defined as $1-\mathrm{L}_{1} / \mathrm{L}_{0}$ with $L_{l}$ being the $\log$-likelihood of the full model and $L_{0}$ being the likelihood of the "constant only" model. $L R$ chi ${ }^{2}$ is the test that at least one of the predictors' regression coefficients is not equal to zero. Dummies for year and regional effects as well as further control variables are not shown. Appendix C contains the full list of explanatory variables.

Similar to the analysis of non-transactors, there is no clear evidence that equity withdrawal is used to buffer negative income shocks, but results indicate that it is a means of borrowing against higher future income to smooth consumption in the medium run. The

\footnotetext{
${ }^{35}$ This could potentially bias the estimates if they also pick up the impact on the decision to move. The small sample size does not allow to estimate a selection equation in this case.

${ }^{36}$ Table D.2 in Appendix D shows average partial effects (APE) for both model specifications.
} 
coefficient of the variable indicating an improved economic situation expected in 5 years' time is significantly positive in both specifications, supporting predictions from the life-cycle theory.

While age effects are absent, retirees seem to have a lower propensity to withdraw when moving. This puzzling result might reflect the impact of being retiree on the decision to move, which would be more in line with the previous finding that among non-transactors they are more likely to withdraw and with results from Chiuri and Jappelli (2008).

Estimates also show that households with children, debt, and lower net worth are more likely to withdraw when moving, suggesting that HEW represents a convenient financing source. However, it is not mainly households in financial need who withdraw home equity during property transaction, as households with higher income turn out to be more prone to withdraw.

Finally, column (2) controls for the financial risk aversion and planning horizon of individuals. In contrast to results for non-transactors, results indicate no significant link to home equity withdrawal.

\section{Conclusion}

This study assesses the factors driving gross home equity withdrawal in the Netherlands and investigates the relative importance of different motives postulated by theory. While there has been much interest in home equity withdrawal and its relationship to consumption from central banks and macro economists, empirical evidence on the household level is still scarce and has so far been limited to the UK, Australia, and the USA. Using a pooled sample of Dutch households over the years 2004 to 2007, this analysis provides the first evidence for continental Europe. The main results are as follows:

First, in contrast to previous studies the analysis finds little support that home equity withdrawal is used as a buffer for negative income shocks. Financial motives seem to be more important, as households with higher outstanding mortgage value have a higher probability to withdraw.

Second, life-cycle effects turn out to be influential. The propensity to withdraw increases until around the age of 50 and decreases afterwards, reflecting that young households first have to build up home equity before they can withdraw it at a later stage. There is also some indication that elderly homeowners use their housing wealth, although mainly by remortgaging or taking out a second mortgage, rather than by moving to cheaper accommodation.

Third, the data do not show that home equity acts as insurance against rising house prices. House price volatility has no significant effect on the propensity to withdraw in the sample of Dutch households. In contrast, the decision to withdraw home equity is driven by expectations about future mortgage interest rates, the financial knowledge an individual has, and their behaviour in financial matters.

Finally, an attempt is made to incorporate changes in supply side conditions into the analysis, an aspect that has been neglected by the literature so far. In general, tightening credit standards have no impact on equity withdrawal over the sample period, but they seem to represent a significant impediment for households facing a negative income shock. It remains for future research to assess the impact of changing supply conditions using longer time periods or regional variation.

How home equity withdrawal on the household level translates into aggregate effects, depends largely on what the equity is spent on. Consistent with international evidence, the Dutch survey indicates that the bulk is reinvested into the housing sector and only a fraction 
spent on consumption goods. This suggests that equity withdrawal feeds back to the economy mainly through the housing sector.

\section{Appendix A: HEW and descriptive statistics}

\section{Box A.1: Definition of home equity withdrawal and injection}

Gross home equity withdrawal (HEW) occurs when households borrow against the equity owned in their homes. This can be done via transactions and/or additional borrowing (see Klyuev and Mills 2007). Households withdraw home equity e.g. when they

- remortgage or refinance their existing mortgage with a higher principal;

- take out a second mortgage;

- move to a new house thereby taking out a higher mortgage than necessary for buying the house itself;

- trade down to a lower value house while decreasing their level of secured debt by less; or

- sell a house to move into rental accommodation.

Households inject (gross) equity into their homes when they

- make a down payment on a house purchase;

- make amortization on a mortgage;

- purchase homes and investment properties with cash or proceeds from (gross) HEW; or

- finance home improvements with cash or through (gross) HEW.

The difference between gross HEW and gross injection of equity into homes is net HEW. Home improvements entirely financed through mortgages have no impact on net HEW, thus net HEW masks a substantial amount of withdrawals reinvested into housing. This study makes use of data about gross HEW provided by the DHS. 
Figure A.1: Growth in house prices and outstanding mortgage value of Dutch households

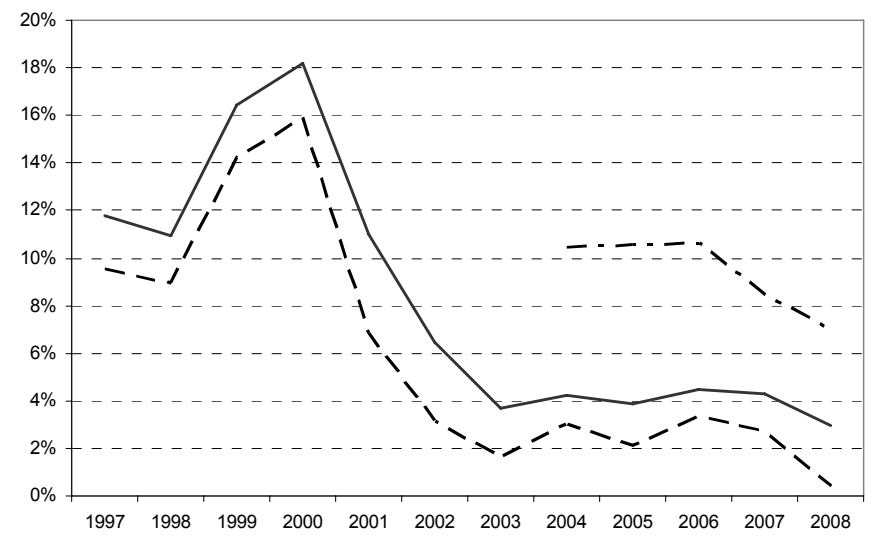

Notes: Yearly percentage change. Source: CBS (Central Bureau of Statistics Netherlands) (house prices) and ECB (mortgages).

Figure A.2: Average mortgage interest rates in the Netherlands

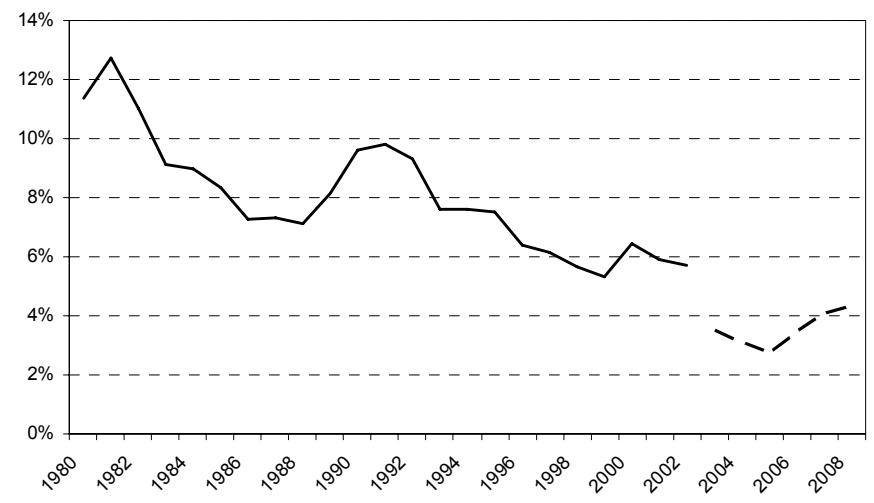

Source: Eurostat (1980-2002), DNB (2003-2008) weighted by new business volumes. Break in 2003.

Figure A.3: HEW (non-transactors)

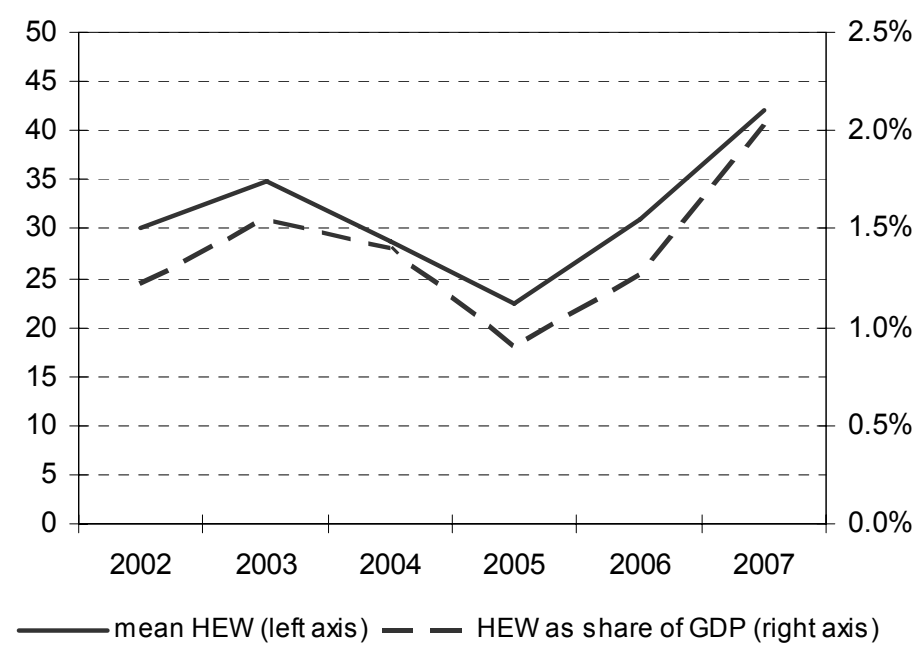

Notes: Average amount withdrawn in $1000 €$ and as share of GDP. Source: DHS and own calculation. 
Figure A.4: HEW (transactors)

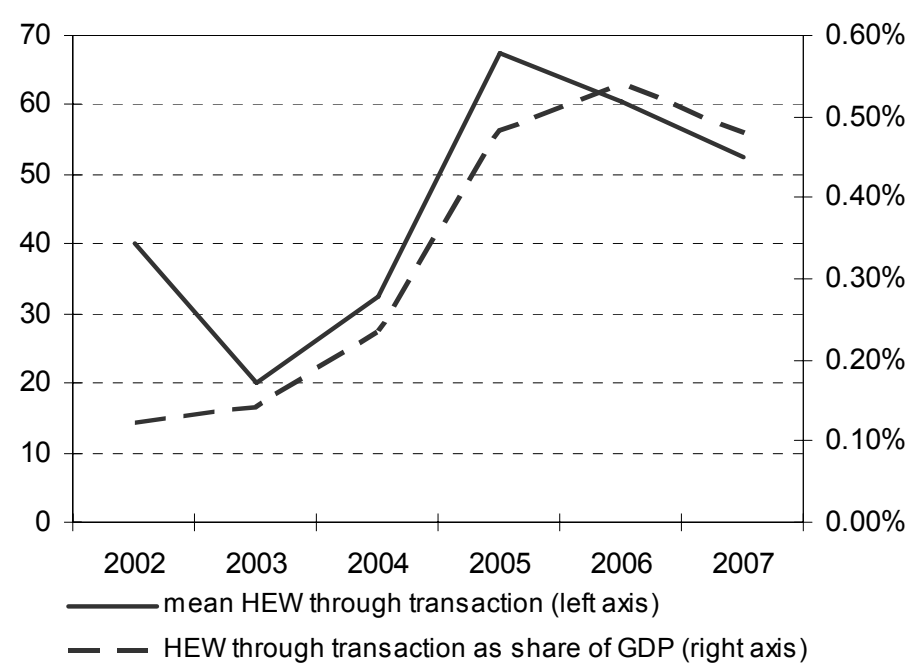

Notes: Average amount withdrawn in $1000 €$ and as share of GDP. Source: DHS and own calculation.

Figure A.5: Change in credit standards and loan demand for house purchases

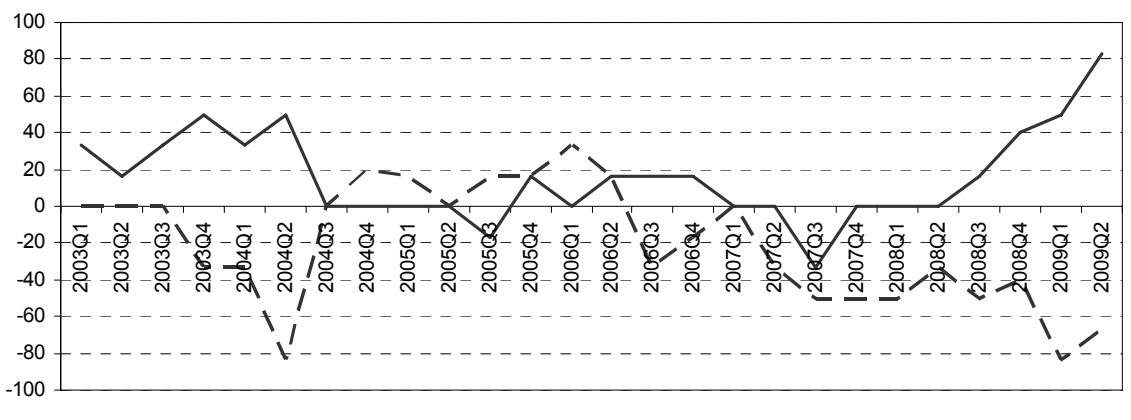

Credit standards loans for house purchases - - demand loans for house purchases

Notes: Data were collected the first calendar day of the quarter and refer to the three-month period just ended. Source: DNB.

Figure A.6: Change in credit standards and demand for consumer credit and other loans

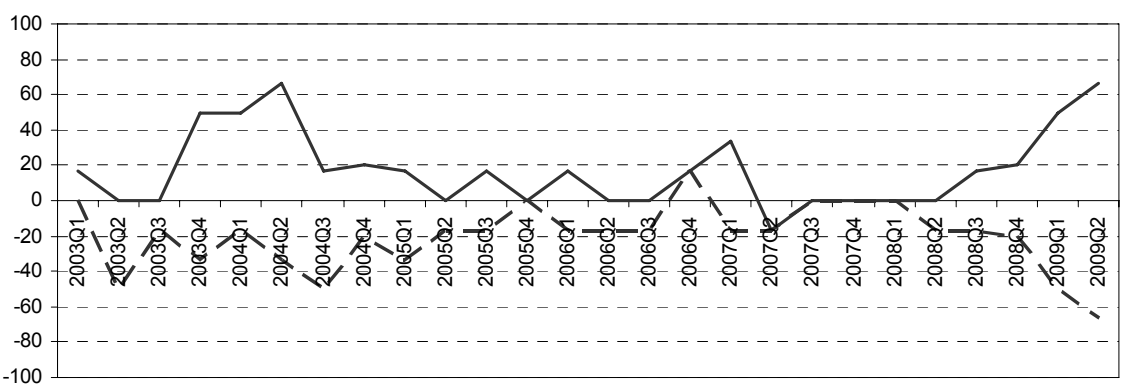

Credit standards for consumer credit and other loans - - demand loans for consumer credit and other loans

Notes: Data were collected the first calendar day of the quarter and refer to the three-month period just ended. Source: DNB. 
Table A.1: Ratio of outstanding residential mortgage to GDP (\%)

\begin{tabular}{|c|c|c|c|c|c|c|c|c|c|c|}
\hline & 1994 & 1995 & 1996 & 1997 & 1998 & 1999 & 2000 & 2001 & 2002 & 2003 \\
\hline Belgium & 21 & 21 & 21 & 23 & 25 & 27 & 27 & 28 & 29 & 27 \\
\hline Czech Rep & & & & & & & & 1 & 2 & 3 \\
\hline Denmark & 65 & 63 & 63 & 71 & 76 & 77 & 76 & 80 & 83 & 88 \\
\hline Finland & 36 & 31 & 30 & 30 & 30 & 31 & 31 & 32 & 34 & 36 \\
\hline France & 21 & 20 & 20 & 21 & 20 & 21 & 22 & 22 & 23 & 25 \\
\hline Germany & 44 & 45 & 48 & 51 & 53 & 57 & 54 & 54 & 54 & 54 \\
\hline Greece & 4 & 4 & 5 & 5 & 6 & 7 & 9 & 12 & 15 & 17 \\
\hline Hungary & & & & & & & & 2 & 5 & 8 \\
\hline Ireland & 23 & 24 & 24 & 24 & 27 & 29 & 32 & 33 & 37 & 45 \\
\hline Italy & 6 & 8 & 7 & 7 & 8 & 9 & 10 & 10 & 11 & 13 \\
\hline Latvia & & & & 0 & 1 & 1 & 2 & 3 & 5 & 8 \\
\hline Luxembourg & 24 & 25 & 24 & 23 & 24 & 24 & 26 & 28 & 30 & 33 \\
\hline Netherlands & 46 & 48 & 52 & 58 & 63 & 69 & 74 & 79 & 88 & 100 \\
\hline Poland & & & 16 & 2 & 2 & 2 & 2 & 3 & 4 & 5 \\
\hline Portugal & 16 & 18 & 22 & 25 & 32 & 39 & 44 & 47 & 50 & 51 \\
\hline Spain & 16 & 17 & 18 & 21 & 24 & 27 & 31 & 34 & 38 & 42 \\
\hline Sweden & 55 & 56 & 51 & 49 & 45 & 47 & 46 & 47 & 48 & 50 \\
\hline United & 55 & 53 & 59 & 55 & 51 & 55 & 56 & 60 & 65 & 70 \\
\hline Average & 31 & 31 & 31 & 29 & 30 & 33 & 34 & 32 & 34 & 38 \\
\hline
\end{tabular}

Source: Housing Statistics in the European Union 2004. 


\section{Appendix B: HEW measured by the DNB Household Survey}

The DNB Household Survey consists of different questionnaires, where the fourth one addresses accommodation and mortgages. Since 2003 additional questions for the DNB have been added to the survey also enriching the information concerning mortgages and home equity withdrawal. At this point one has to distinguish between HEW without moving and HEW through transactions.

For the former, only the last wave of 2008 asks explicitly about HEW in the previous year, i.e. 2007. All other waves from 2003 to 2007 gather information about HEW in the past five to six years preceding the time of the interview. The following excerpts from the survey of 2007 show which questions have been asked and what information has been obtained.

\section{*WOD44C}

This question is about the surplus value on your house. Surplus value is the difference between the selling value or the market value of a house and the remaining debt on the mortgage.

Have you once or several times used the surplus value in the past 3 years (i.e. since January 2002)?

For example by taking out an additional mortgage or by taking out the existing mortgage anew (and at the same time increasing it) (without moving).

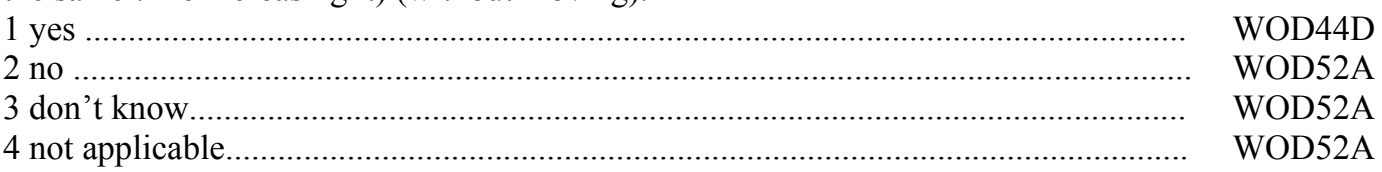

*WOD44D

What is the total amount? If you do not know exactly, please give an estimate.

Please give the amount in thousands of euros, so 180,000 is 180 .

amount

WOD44E1

999999 don’t know WOD44F 1

*WOD44E1 thru *WOD44E5 (amounts for 5 years)

Can you indicate which amount you used in which year? If you don't know exactly, you can give an estimate. If you really don't know, you can leave the answer empty. If you haven't used (part of) the money in a particular year, please type 0 (zero). Please give the amount in thousands of euros, so 180,000 is 180 .

12002 : amoun

WOD44F 1

22003 : amount WOD44F1

32004 : amount WOD44F1

42005 : amount WOD44F1

52006 : amount WOD44F

62007 : amount WOD44F1

Note: the year 2000 is used by mistake in this question (WOD44E1).

Soft check: "If added in total this is [total2 (x 1000 euro)]. This amount is higher than the total amount [total] given earlier (x 1000 euro). You may go back to change the answers.

*WOD44F01 thru *WOD44F13

Where did you use the surplus value for? (More than 1 answer possible.)

1 property improvement (renovating house, kitchen etc.)

WOD44H01

2 purchase of real estate (land, holiday house etc.).. WOD44H01

3 business investment WOD44H01

4 purchase of durable goods (car, boat etc.)..

WOD44H01

5 purchase of electronic equipment, furniture WOD44H01

6 holiday, world trip, party etc.

WOD44H01

7 savings account

WOD44H01

8 purchase of stocks/ investments.

WOD44H01

9 pension arrangements/ old-age/ early retirement/ life insurance

WOD44H01

10 education of the children

WOD44H01

11 paying off other loans

WOD44H01

12 otherwise.

WOD44G

13 don't know

WOD52A 
To use the information for the econometric analysis employed in this study, an indicator variable has to be constructed, which tells us whether an individual has withdrawn home equity in a certain year. If a positive value has been withdrawn during a year as assessed by WOD44E1 through WOD44E5, the indicator variable gets the value of 1 and if no money has been withdrawn it gets the value of 0 . This information is then cross-checked with question WOD44C. If the individual states that they have not withdrawn home equity in any of the previous years, the values of the indicator variable for these years are replaced by 0 .

Given that we have overlapping information about HEW in a certain year prior to 2007, different approaches could be followed. First, one could just rely on information assessed in wave 2007, secondly one could use the latest wave in which an individual is observed as source of information, and thirdly one could try to combine the information from several waves to improve the quality of the data. The last approach is the one followed in this study. Starting from 2002, I use for each year the information available in the survey of the following year, i.e. in $t+1$. Should the information be missing, I proceed to $t+2$ and update my knowledge about HEW in $t$. This procedure continues until 2007 and cross-checks the information with WOD44C as explained before.

Although all of the three approaches have their advantages and disadvantages, the method employed in the paper and outlined above has some attractive characteristics. By always using the information from the next wave and only updating it if it is missing, it takes into account that individuals usually have a better memory about recent events. Furthermore, it could alleviate measurement error, if in later waves the individual mistakenly states the wrong year in which the HEW should have taken place.

Regarding HEW through transactions, the DNB household survey asks the following question in each wave:

*WOD72B Have you used the surplus value, e.g. by moving to cheaper accommodation or by taking out a higher mortgage than necessary for buying the house itself?

1 yes WOD72B

2 no WOD72F

This information is then matched with the information regarding the individual in the year the home was bought, which is assessed in question WOD35B.

*WOD35B In which year did you buy your current house?

year. WOD35AA 


\section{Appendix C: Explanatory variables ${ }^{37}$}

\author{
buffer motive \\ shock income \\ shock health \\ $\Delta$ marital status

\section{financial motive} \\ mortgage outstanding \\ $\Delta^{1}$ house price \\ $\Delta^{\mathrm{K}}$ house price \\ surplus \\ $\operatorname{tax}$
}

life-cycle motive

future economic situation

future economic situation ${ }^{+}$

age

retired

\section{insurance \\ house price volatility}

other controls

household income

net worth

debt

loan constraint

income problem

rate exp increase

hew planned income is 'unusually low' compared to the income expected in a regular year (INKNORM) [1-5, 1t-2t]

health is 'somewhat' or 'much worse' compared to one year ago (GEZ4) [15, 9-10]

indicates whether the individual got married or divorced (BURGST) [3-5]

total amount mortgages on the house in $1000 €$ if amount $<1.5 \mathrm{~m} €$ (b26hyb/1000) [1-5]

difference between the self-assessed selling value of the house in $t$ and $t-1$ [1-5]

difference between the self-assessed market value of the house in $t$ and the CPI adjusted purchase price in $t-K$ in $1000 €$ (WO41-WO34) [1-5]

difference between the self-assessed market value and the remaining mortgage debt on the house in $1000 €$; values between $1^{\text {st }}$ and $99^{\text {th }}$ percentile (b26ogb/1000-b26hyb/1000) [2, 4-5]

tax rate estimated as [gross income-net income]/[gross income-mortgage interest payments] (btot, ntot, htr) [1-5]

in five years' time the economic situation of the household will be 'worse' or 'much worse' (ECSIT) [1-5, 1t-2t]

in five years' time the economic situation of the household will be 'better' or 'much better' (ECSIT) [1, 3-5, 1t-2t]

age in years defined as the difference between survey year and birth year (GEBJAAR) [1-5, 1t-2t]

indicates whether the individual is retired (BELBEZIG, BEZIGBEL, BEZIGHEI) [2, 4-5, 1t-2t]

standard deviation of the regional house price index in the five years preceding the interview [4-5]

sum of the net income of the household members weighted by the OECD equivalence scale in $1000 €$ if amount $<2.3 \mathrm{~m} €($ ntot $)[1-5,1 \mathrm{t}-2 \mathrm{t}]$

total assets - total debt in $1000 €[1-5,1 \mathrm{t}-2 \mathrm{t}]$

indicates whether an individual has any of different types of debt (credit card -, private -, credit line -, purchase -, family -, other debt)

(CRED1, PERS1, DOOR1, FINA1, ANDE1, FAMI1) [1-5, 1t-2t]

indicates whether an individual 'disagrees' or 'totally disagrees' with the statement 'I can easily obtain a loan' (LOAN2) [2, 4-5]

indicates whether it is 'hard' or 'very hard' to manage on the income of the household (INKROND) [2, 4-5]

indicates whether one expects the mortgage interest rates to be 'higher than now' in two years time (WOD52A) [2, 4-5]

indicates whether one is 'probably' or 'certainly' withdrawing home equity in the next two years [2, 4-5]

\footnotetext{
${ }^{37}$ Variable labels from DHS are in brackets. Numbers in square brackets refer to the use of the variable in the respective regression specification (see tables 3 and 4). Specifications for transactors are indicated with a ' $t$ ' close to the number. The robustness analysis in Table E.1 follows specification (4) in Table 4, except that (shock income $^{-}$) and ( $\Delta$ marital status) are dropped in column (3).
} 
mover

financial risk averseness

time horizon

spending

financial knowledge

higher education

female

assets

urban

house price exp decrease

tax deductibility

children

couple

year*

region*

indicates whether the individual is looking for another accommodation or has already found one (WO53) [2, 4-5]

indicates whether one would never consider investments in shares (value six or seven for SPAAR2) [2, 4-5, 2t]

indicates whether the personal time horizon for planning expenditures and savings is the next couple of years, the next 5 to 10 years or more than 10 years (dummy $=1)$ or the next couple of months or the next years (dummy $=0$ ) (PERIODE1) [2, 4-5, 2t]

indicates whether an individual likes to spend all her/his money immediately (value $<4$ for UITGEVEN) [4-5]

indicates whether one considers herself as 'knowledgeable' or 'very knowledgeable' in financial matters (KUNDE) [2, 4-5]

highest level of education attended is university (OPLZON) [1-5, 1t-2t]

indicates the sex of the individual (GESLACHT) [1-5, 1t-2t]

indicates whether one owns liquid assets in one of the following forms: current account credit, savings account, deposit book, savings certificate, mutual funds, bonds or shares (bet131, bz03, bz04, bz06, bz12, bz13, bz14) $[2,4-5,1 \mathrm{t}-2 \mathrm{t}]$

indicates whether the degree of urbanization of the town/city of residence is 'high' or 'very high' (STED) [1-5, 1t-2t]

indicates whether one expects the value of the own house to decrease in the next two years (WO44A) [1-2, 4-5]

indicates whether one expects limitations in the deductibility of mortgage interest rates in the foreseeable future (WOD52F) [1-2, 4-5]

indicates whether there are children in the household (AANTALKI)

$[2,4-5,1 \mathrm{t}-2 \mathrm{t}]$

indicates whether a partner is present in the household (PARTNER)

$[2,4-5,1 \mathrm{t}-2 \mathrm{t}]$

year dummies $[3-4,1 \mathrm{t}-2 \mathrm{t}]$

dummies for the regions 'North', 'East', 'South' and 'other West', with 'three largest cities' being the reference category (REGIO) [1-5, 1t-2t]

mortgage characteristics endowment mortg.

indicates whether the mortgage with the highest value left is an endowment mortgage (HYP51 through HYP55) [1-5]

mortg. guarantee

her

her $>0.35$

nrm

fixed interest

indicates whether the mortgage with the highest value left has a national mortgage guarantee (NHG) (HYP11 through 15) [1-5]

home expenditure ratio (her): ratio between total mortgage expenditure and net household income (HY61 through HY65, ntot) [1-5] if her $>0$ and her $\leq 1$ indicates whether her is $>0.35$ [1-5]

indicates whether the mortgage with the highest value left is a non repayment mortgage (NRM) (HYP51-55) [1-5]

indicates whether the interest rate on the mortgage with the highest value left is fixed (HY71 through HY75) [1-5]

supply side conditions

credit stand. (house purchase)

credit stand. (other) refers to loans/mortgages granted for house purchase. Measured as net percentage, the variable shows the proportion of banks tightening their credit terms and conditions to banks easing them. It reflects the opinion of the six Dutch banks taking part in the bank lending survey. [5] refers to loans/mortgages granted for consumption purpose and other use [5] 
Appendix D: Average partial effects and robustness analysis

Table D.1: Average partial effects (APE) (non-transactors)

\begin{tabular}{|c|c|c|c|c|c|c|}
\hline & & \multicolumn{2}{|c|}{2007} & \multicolumn{3}{|c|}{ 2004-2007 } \\
\hline & & (1) & (2) & (3) & (4) & (5) \\
\hline \multicolumn{7}{|c|}{ buffer motive } \\
\hline & shock inc ${ }^{-}$ & 0.239 & 0.016 & 0.038 & -0.038 & 0.184 \\
\hline & & $(0.159)$ & $(0.836)$ & $(0.646)$ & $(0.260)$ & $(0.331)$ \\
\hline & shock health ${ }^{-}$ & $-0.073 * * *$ & $-0.081 * * *$ & 0.012 & 0.004 & 0.005 \\
\hline & & $(0.000)$ & $(0.000)$ & $(0.595)$ & $(0.888)$ & $(0.849)$ \\
\hline & $\Delta$ maritial status & & & 0.107 & 0.086 & 0.108 \\
\hline & & & & $(0.414)$ & $(0.362)$ & $(0.302)$ \\
\hline \multicolumn{7}{|c|}{ financial motive } \\
\hline & mortgage outstanding $(\mathrm{t}-1)$ & 0.000 & 0.000 & $0.000 * * *$ & $0.000^{* * *}$ & $0.000^{* * *}$ \\
\hline & & $(0.651)$ & $(0.602)$ & $(0.002)$ & $(0.005)$ & $(0.006)$ \\
\hline & $\Delta \mathrm{k}$ house price & 0.000 & $-0.000^{* * *}$ & 0.000 & -0.000 & -0.000 \\
\hline & & $(0.984)$ & $(0.005)$ & $(0.553)$ & $(0.742)$ & $(0.741)$ \\
\hline & $\Delta 1$ house price & $0.001 *$ & $0.002 * * *$ & 0.000 & 0.000 & 0.000 \\
\hline & & $(0.052)$ & $(0.000)$ & $(0.295)$ & $(0.133)$ & $(0.143)$ \\
\hline & surplus $(\mathrm{t}-1)$ & & 0.000 & & 0.000 & 0.000 \\
\hline & & & $(0.142)$ & & $(0.602)$ & $(0.664)$ \\
\hline \multicolumn{7}{|c|}{ life-cycle motive } \\
\hline & age & $0.019^{*}$ & $0.043 * * *$ & 0.006 & $0.012 * *$ & $0.013 * *$ \\
\hline & & $(0.065)$ & $(0.006)$ & $(0.249)$ & $(0.042)$ & $(0.026)$ \\
\hline & $\mathrm{age}^{2}$ & $-0.000^{*}$ & $-0.000 * *$ & -0.000 & $-0.000^{*}$ & $-0.000^{* *}$ \\
\hline & & $(0.064)$ & $(0.012)$ & $(0.359)$ & $(0.051)$ & $(0.030)$ \\
\hline & retired & & 0.070 & & 0.056 & 0.057 \\
\hline & & & $(0.318)$ & & $(0.239)$ & $(0.237)$ \\
\hline & future economic situation ${ }^{\circ}$ & 0.067 & $0.127 * *$ & -0.004 & -0.004 & -0.005 \\
\hline & & $(0.133)$ & $(0.041)$ & $(0.857)$ & $(0.831)$ & $(0.799)$ \\
\hline & future economic situation ${ }^{+}$ & $-0.061^{* * * *}$ & & 0.027 & 0.020 & 0.022 \\
\hline & & $(0.000)$ & & $(0.258)$ & $(0.416)$ & $(0.385)$ \\
\hline \multicolumn{7}{|l|}{ insurance } \\
\hline & regional house price volatility & & & & 2.098 & 2.503 \\
\hline & & & & & $(0.463)$ & $(0.355)$ \\
\hline other cont & & & & & & \\
\hline & household income & 0.000 & $-0.006 *$ & -0.000 & -0.003 & -0.002 \\
\hline & & $(0.991)$ & $(0.085)$ & $(0.905)$ & $(0.187)$ & $(0.370)$ \\
\hline & household income ${ }^{2}$ & -0.000 & $0.000^{* *}$ & -0.000 & 0.000 & -0.000 \\
\hline & & $(0.391)$ & $(0.044)$ & $(0.381)$ & $(0.975)$ & $(0.800)$ \\
\hline & net worth & 0.000 & $0.000^{* * * *}$ & 0.000 & 0.000 & 0.000 \\
\hline & & $(0.130)$ & $(0.002)$ & $(0.549)$ & $(0.265)$ & $(0.420)$ \\
\hline & debt & 0.085 & 0.029 & $0.095^{* *}$ & $0.130^{* * *}$ & $0.139 * * *$ \\
\hline & & $(0.263)$ & $(0.474)$ & $(0.012)$ & $(0.003)$ & $(0.002)$ \\
\hline & credit constraint & & 0.075 & & 0.140 & $0.137 *$ \\
\hline & & & $(0.267)$ & & $(0.101)$ & $(0.098)$ \\
\hline & income problem & & 0.003 & & -0.016 & -0.014 \\
\hline & & & $(0.952)$ & & $(0.642)$ & $(0.703)$ \\
\hline & rate exp increase & & 0.078 & & $0.041^{*}$ & $0.035^{*}$ \\
\hline & & & $(0.202)$ & & $(0.050)$ & $(0.091)$ \\
\hline & hew planned (t-1) & & $0.154 * * *$ & & $0.160^{* * *}$ & $0.154 * * *$ \\
\hline & & & $(0.001)$ & & $(0.002)$ & $(0.002)$ \\
\hline & mover & & $-0.067^{* * *}$ & & $-0.074 * * *$ & $-0.075^{* * * *}$ \\
\hline & & & $(0.000)$ & & $(0.000)$ & $(0.000)$ \\
\hline & financial risk aversion & & -0.008 & & $-0.034 * *$ & $-0.035^{* *}$ \\
\hline & & & $(0.770)$ & & $(0.013)$ & $(0.011)$ \\
\hline & time horizon & & $-0.150^{* * * *}$ & & $-0.027^{*}$ & $-0.030^{*}$ \\
\hline & & & $(0.000)$ & & $(0.086)$ & $(0.055)$ \\
\hline & spending & & & & $-0.065^{* * *}$ & $-0.064 * * *$ \\
\hline & & & & & $(0.000)$ & $(0.000)$ \\
\hline & educ_high & & & & & \\
\hline & & & $(0.132)$ & & $(0.075)$ & $(0.067)$ \\
\hline mortgage & eristics & & & & & \\
\hline & endowment mortg. (t-1) & & & 0.137 & 0.095 & 0.079 \\
\hline & & & & $(0.189)$ & $(0.261)$ & $(0.326)$ \\
\hline & mortg. guarantee $(\mathrm{t}-1)$ & & & $0.045^{*}$ & 0.040 & $0.042^{*}$ \\
\hline & & & & $(0.084)$ & $(0.108)$ & $(0.100)$ \\
\hline & her $>0.35$ & & & $-0.051^{* * * *}$ & $-0.064 * * *$ & $-0.063 * * *$ \\
\hline & & & & $(0.010)$ & $(0.000)$ & $(0.000)$ \\
\hline supply sid & ions & & & & & \\
\hline & credit stand. (house purchase) & & & & & -0.000 \\
\hline & & & & & & $(0.929)$ \\
\hline & credit stand. (other) & & & & & -0.002 \\
\hline & & & & & & $(0.658)$ \\
\hline & shock inc ${ }^{-} \mathrm{x}$ credit stand. (other) & & & & & $-0.015^{* *}$ \\
\hline & & & & & & $(0.049)$ \\
\hline & Observations/(Households) & 242 & 242 & $892 /(429)$ & $796 /(393)$ & $796 /(393)$ \\
\hline & Pseudo- $R^{2}$ & 0.420 & 0.665 & 0.144 & 0.275 & 0.269 \\
\hline & LR chi $^{2}$ & 86.988 & 101.296 & 88.600 & 182.140 & 187.054 \\
\hline & $\mathrm{Chi}^{2} \mathrm{p}$-value & 0.000 & 0.000 & 0.000 & 0.000 & 0.000 \\
\hline
\end{tabular}

Notes: See Table 4. 


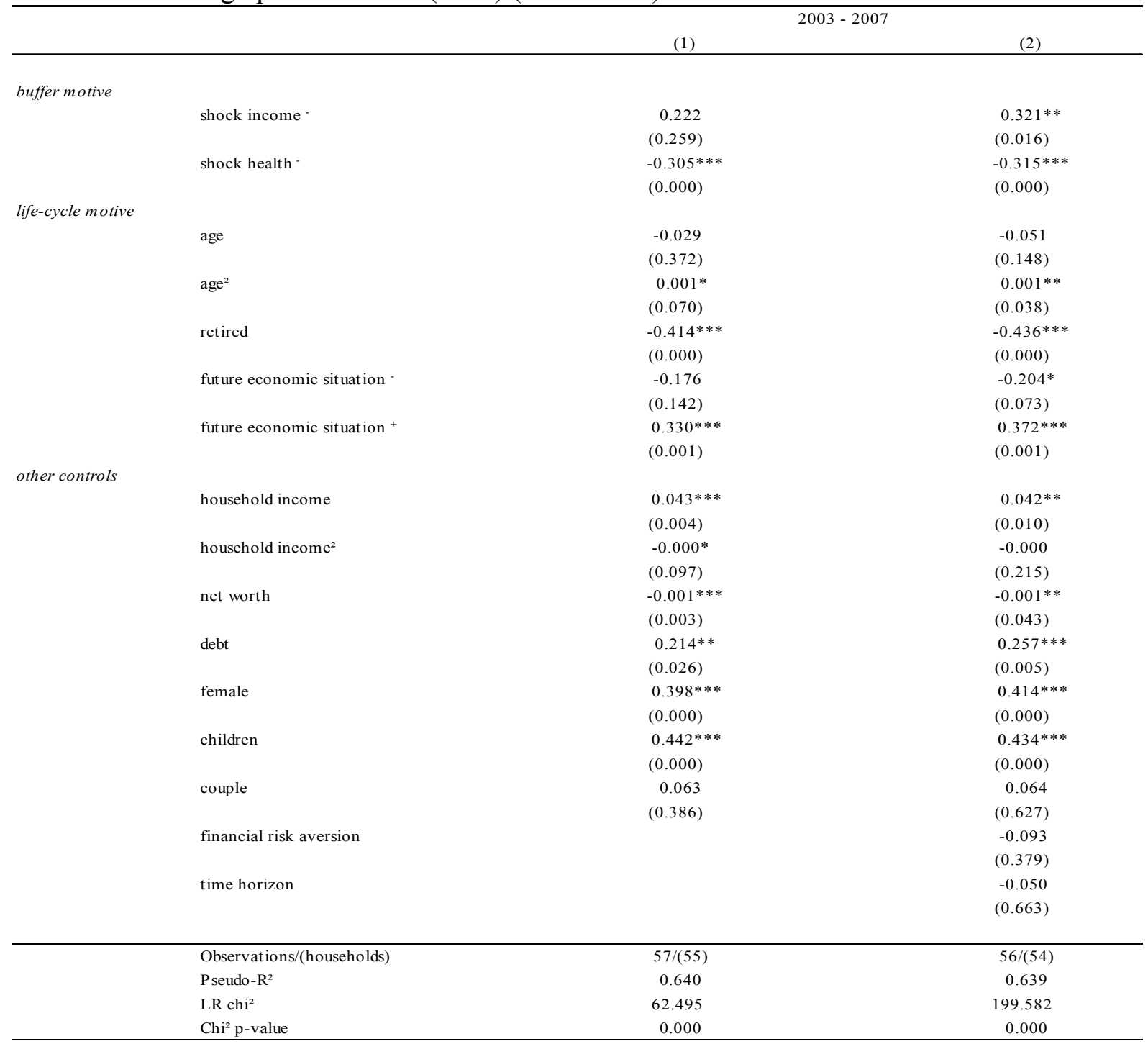

Notes: See Table 5.

\section{Appendix E: Robustness analysis}

To check the stability of the results, specification (4) in Table 4 is re-estimated after removing potential outliers from the sample. Column (1) in Table E.1 shows results when leaving out observations with a very high value for Cook's distance, in column (2) observations with large deviance residuals are removed, and in column (3) observations with high leverage according to the hat-value are missing. As cut-off values a Cook's distance $>0.4$ (2 observations removed), a deviance residual $>2.1$ (16 observations) and a hat-value $>0.2$ (33 observations) have been chosen. These are motivated by residual analysis and common rules of thumb (deviance $>0.2$, hat-value $>3 \times$ mean(leverage)) and have taken into account a possible further loss of observations due to missing variation in some of the variables in the reduced sample. The main results from the analysis do not change, showing that estimates are robust to the exclusion of outlying observations. 
Table E.1: Regression analysis adjusted for potential outliers

\begin{tabular}{|c|c|c|c|c|}
\hline & & & $004-2007$ & \\
\hline & & (1) & (2) & (3) \\
\hline buffer mot & & & & \\
\hline & shock income ${ }^{-}$ & -0.747 & -0.258 & \\
\hline & & $(0.216)$ & $(0.692)$ & \\
\hline & shock health ${ }^{-}$ & 0.060 & -0.075 & -0.017 \\
\hline & & $(0.801)$ & $(0.820)$ & $(0.945)$ \\
\hline & $\Delta$ maritial status & 0.749 & $1.133^{* *}$ & \\
\hline & & $(0.139)$ & $(0.033)$ & \\
\hline financial $n$ & & & & \\
\hline & mortgage outstanding (t-1) & $0.004^{* *}$ & $0.006^{* * *}$ & $0.005^{* * *}$ \\
\hline & & $(0.031)$ & $(0.007)$ & $(0.010)$ \\
\hline & $\Delta \mathrm{k}$ house price & 0.001 & 0.000 & -0.000 \\
\hline & & $(0.367)$ & $(0.906)$ & $(0.787)$ \\
\hline & $\Delta 1$ house price & 0.002 & 0.003 & $0.006^{* *}$ \\
\hline & & $(0.393)$ & $(0.339)$ & $(0.037)$ \\
\hline & surplus $(\mathrm{t}-1)$ & -0.001 & 0.000 & 0.001 \\
\hline & & $(0.426)$ & $(0.876)$ & $(0.583)$ \\
\hline life-cyclen & & & & \\
\hline & age & $0.115^{* *}$ & $0.183^{* *}$ & $0.097^{*}$ \\
\hline & & $(0.040)$ & $(0.021)$ & $(0.083)$ \\
\hline & age $^{2}$ & $-0.001 *$ & $-0.002^{* *}$ & -0.001 \\
\hline & & $(0.056)$ & $(0.024)$ & $(0.117)$ \\
\hline & retired & 0.433 & $0.892^{* *}$ & 0.292 \\
\hline & & $(0.178)$ & $(0.010)$ & $(0.399)$ \\
\hline & future economic situation - & -0.049 & 0.032 & -0.151 \\
\hline & & $(0.814)$ & $(0.898)$ & $(0.525)$ \\
\hline & future economic situation $^{+}$ & 0.258 & 0.293 & 0.345 \\
\hline & & $(0.215)$ & $(0.267)$ & $(0.117)$ \\
\hline insurance & & & & \\
\hline & regional house price volatility & 18.559 & $64.804 * *$ & 23.714 \\
\hline & & $(0.490)$ & $(0.047)$ & $(0.406)$ \\
\hline other cont & & & & \\
\hline & household income & -0.021 & -0.022 & -0.022 \\
\hline & & $(0.350)$ & $(0.526)$ & $(0.361)$ \\
\hline & household income ${ }^{2}$ & -0.000 & -0.000 & -0.000 \\
\hline & & $(0.855)$ & $(0.438)$ & $(0.866)$ \\
\hline & net worth & 0.001 & 0.001 & 0.001 \\
\hline & & $(0.241)$ & $(0.102)$ & $(0.419)$ \\
\hline & debt & $0.909^{* * *}$ & $1.560 * * *$ & $0.983^{* * *}$ \\
\hline & & $(0.000)$ & $(0.000)$ & $(0.000)$ \\
\hline & credit constraint & $0.834^{* *}$ & $0.879^{* *}$ & $1.282^{* *}$ \\
\hline & & $(0.041)$ & $(0.033)$ & $(0.013)$ \\
\hline & income problem & -0.627 & -0.670 & 0.310 \\
\hline & & $(0.185)$ & $(0.232)$ & $(0.382)$ \\
\hline & rate exp increase & $0.429^{* * *}$ & $0.500^{* *}$ & $0.404^{* *}$ \\
\hline & & $(0.010)$ & $(0.044)$ & $(0.015)$ \\
\hline & hew planned (t-1) & $0.983^{* * *}$ & $1.748^{* * *}$ & $1.071^{* * *}$ \\
\hline & & $(0.000)$ & $(0.000)$ & $(0.000)$ \\
\hline & mover & $-1.509^{* * *}$ & $-1.207 * * *$ & $-1.622^{* * *}$ \\
\hline & & $(0.001)$ & $(0.002)$ & $(0.000)$ \\
\hline & financial risk aversion & $-0.402 * *$ & $-0.699 * * *$ & $-0.344^{* *}$ \\
\hline & & $(0.021)$ & $(0.003)$ & $(0.049)$ \\
\hline & time horizon & -0.277 & $-0.645^{* * *}$ & -0.192 \\
\hline & & $(0.105)$ & $(0.006)$ & $(0.267)$ \\
\hline & spending & $-1.001^{* *}$ & $-1.505^{* * *}$ & $-0.854^{* *}$ \\
\hline & & $(0.012)$ & $(0.008)$ & $(0.020)$ \\
\hline & financial knowledge & $0.304 *$ & $0.499 * *$ & 0.272 \\
\hline & & $(0.075)$ & $(0.021)$ & $(0.128)$ \\
\hline mortgage & & & & \\
\hline & endowment mortg. (t-1) & 0.654 & $1.166^{* *}$ & $0.996^{* *}$ \\
\hline & & $(0.147)$ & $(0.027)$ & $(0.033)$ \\
\hline & mortg. guarantee (t-1) & $0.352^{*}$ & 0.181 & $0.438^{* *}$ \\
\hline & & $(0.058)$ & $(0.459)$ & $(0.026)$ \\
\hline & her $>0.35$ & $-1.130^{* *}$ & $-1.828^{* * *}$ & $-0.971^{* *}$ \\
\hline & & $(0.011)$ & $(0.008)$ & $(0.032)$ \\
\hline & Observations/(households) & $794 /(393)$ & $780 /(389)$ & $796 /(373)$ \\
\hline & Pseudo- $\mathrm{R}^{2}$ & 0.289 & 0.482 & 0.287 \\
\hline & LR chi $^{2}$ & 172.330 & 243.928 & 143.366 \\
\hline & $\mathrm{Chi}^{2} \mathrm{p}$-value & 0.000 & 0.000 & 0.000 \\
\hline
\end{tabular}

Notes: See Table 4. The regression analysis follows specification (4) in Table 4. 


\section{References}

Angelini, V. (2006). Mortgage Refinancing and Consumption Smoothing. University of York Discussion Papers in Economics No. 2006/26.

Angelini, V. and Simmons, P. (2005). Housing debt, employment risk and consumption. University of York Discussion Papers in Economics No. 2005/07.

Aoki, K., Proudman, J. and Vlieghe, G. (2004). House prices, consumption, and monetary policy: a financial accelerator approach. Journal of Financial Intermediation, 13, 414-435.

Banks, J., Blundell, R., Oldfield, Z. and Smith, J.P. (2004). House price volatility and housing ownership over the life cycle. University College London Discussion Paper No. 04-09.

Benito, A. (2009). Who Withdraws Housing Equity and Why? Economica, 76, 51-70.

Benito, A. and Power, J. (2004). Housing Equity and Consumption: Insights from the Survey of English Housing. Bank of England Quarterly Bulletin, 44, 302-309.

Boelhuwer, P.J. (2002). Capital accumulation via homeownership: the case of the Netherlands. European Journal of Housing Policy, 2 (2), 167-181.

Boone, L., Girouard, N. and Wanner, I. (2001). Financial Market Liberalisation, Wealth and Consumption. OECD Economics Department working paper No. 308.

Buiter, W.H. (2008). Housing wealth isn't wealth. NBER Working Paper 14204.

Campbell, J.Y. and Cocco J.F. (2007). How do house prices affect consumption? Evidence from micro data. Journal of Monetary Ecnomics, 54, 591-621.

Canner, G., Dynan, K. and Passmore, W. (2002). Mortgage Refinancing in 2001 and Early 2002. Federal Reserve Bulletin, 88, 469-481.

Case, K.E., Quigley, J. and Shiller, R. (2005). Comparing wealth effects: the stock market versus the housing market, Advances in Macroeconomics, 5 (1), article 1.

Chiuri, M.C. and Jappelli, T. (2008). Do the elderly reduce housing equity? An international comparison. Journal of Population Economics, DOI 10.1007/s00148-008-0217-4.

Debelle, G. (2004). Household debt and the macroeconomy. BIS Quarterly Review, March.

DNB (2003). Quarterly Bulletin, September.

DNB (2008). Overview of Financial Stability in the Netherlands, September.

Dol, K. and Neuteboom, P. (2008). Housing policies in a rapidly changing world. Government financial measures to promote homeownership and housing affordability in the Netherlands. (Study on behalf of Statens Bostadskreditnämnd (BKN)). 
Dvornak, N. and Kohler, M. (2007). Housing Wealth, Stock Market Wealth and Consumption: A Panel Analysis for Australia. Economic Record, 83 (261), 117-130.

ECB (2001). Regulation (EC) No 2423/2001 of the European Central Bank of 22 November 2001 concerning the consolidated balance sheet of the monetary financial institutions sectors. http://www.ecb.int/ecb/legal/pdf/1_33320011217en00010046.pdf.

Hurst, E. and Stafford, F. (2004). Home is where the equity is: mortgage refinancing and household consumption. Journal of Money, Credit and Banking, 36, 985-1014.

Holmans, A.E. (2001). Housing and Mortgage Equity Withdrawal and Their Component Flows: A Technical Report. Council of Mortgage Lenders, London, http://cml.org.uk.

Iacoviello, M. (2005). House prices, borrowing constraints and monetary policy in the business cycle. American Economic Review, 95, 739-764.

Khandani, A.E., Lo, A.W. and Merton, R.C. (2009). Systemic risk and the refinancing ratchet effect. NBER Working Paper No. 15362.

Klyuev V. and Mills, P. (2007). Is Housing Wealth an "ATM"? The Relationship Between Household Wealth, Home Equity Withdrawal, and Saving Rates. IMF Staff Papers, 54, 539-561.

Manchester, J. and Poterba, J. (1989). Second Mortgages and Household Saving. Regional Science and Urban Economics, 19, 325-346.

Mercer Oliver Wyman (2003). Study on the Financial Integration of European Mortgage Markets. European Mortgage Federation.

Mian, A.R. and Sufi, A. (2009). House prices, home-equity-based borrowing, and the U.S. household leverage crisis. NBER Working Paper No. 15283.

Muellbauer, J. and Murphy, A. (1990). Booms and busts in the UK housing market? Economic Journal, 107, 1701-1727.

Muellbauer, J. and Murphy, A. (1997). Is the UK balance of payments sustainable? Economic Policy, 11, 345-383.

National Board of Housing, Building and Planning Sweden and Ministry for Regional Development of the Czech Republic (ed.) (2005). Housing Statistics in the European Union 2004. Karlskrona: Boverket.

Scanlon, K., Lunde, J. and Whitehead, C. (2008). Mortgage Product Innovation in Advanced Economies: More Choice, More Risk. European Journal of Housing Policy, 8 (2), 109131.

Schwartz, C., Lewis, C. and Norman, D. (2008). Factors Influencing Housing Equity Withdrawal: Evidence from a Microeconomic Survey. Economic Record, 84 (267), 421 433. 
Sinai, T. and Souleles, N. (2005). Owner-occupied housing as a hedge against rent risk. Quarterly Journal of Economics, 120, 763-789.

Smith, S.J. and Searle, B.A. (2008). Dematerialising Money? Observations on the Flow of Wealth from Housing to Other Things. Housing Studies, 23 (1), 41-43.

Van Dijkhuizen, A. (2005) Dutch housing finance market. Basel: Bank for International Settlements, http://www.bis.org/publ/wgpapers/cgfs26dijkhuizen.pdf.

Wooldridge, J.M. (2002). Econometric analysis of cross Section and panel data. Cambridge, Massachusetts: MIT Press. 